\title{
The hydrothermal system of Bagni San Filippo (Italy): fluids circulation and $\mathrm{CO}_{2}$ degassing
}

\author{
Giovanni Chiodini (1), Carlo Cardellini (2), Stefano Caliro (3), Rosario Avino (3), Marco Donnini (4), \\ Domenico Granieri (5), Nicola Morgantini (6), Domenico Sorrenti (7) \& Francesco Frondini (2)
}

\begin{abstract}
Bagni San Filippo area is characterized by the discharge of thermal waters and deeply produced $\mathrm{CO}_{2}$-rich gases both from vents and soil diffuse degassing. The thermal waters are the results of the mixing between meteoric waters and hot fluids deriving from the condensation, at depth, of vapours uprising from a deep hydrothermal reservoir. This process gives rise to a relatively shallow thermal system at temperature close to $50^{\circ} \mathrm{C}$, characterized by $\mathrm{SO}_{4}$-rich and $\mathrm{Cl}$-poor waters and elevated $\mathrm{P}_{\mathrm{Cg} 2}(\sim 7 \mathrm{bar})$. Most of the incondensable gas of deep originated vapour is released as a free gas phase forming cold gas vents and localized spots of anomalous $\mathrm{CO}_{2}$ diffuse degassing. The location and the shape of these degassing zones are strongly controlled by the main tectonic structures of the area. Through detailed soil diffuse degassing surveys and hydrogeochemical modelling, we estimate at 226-326 t d $\mathrm{d}^{-1}$ and at $965 \mathrm{t} \mathrm{d}^{-1}$ the deep $\mathrm{CO}$ emission and the amount of condensates discharged by the thermal springs, respectively. The thermal energy associated to the process results at $\sim 29 \mathrm{MW}$, most of which ( $25 \mathrm{MW})$ is associated with condensation occurring at depths greater than groundwater circulation.
\end{abstract}

KEY wORDS: $\mathrm{CO}_{2}$ diffuse degassing, thermal waters, geothermal system.

\section{INTRODUCTION}

Central-southern Italy is affected by an active and intense process of $\mathrm{CO}_{2}$ Earth degassing from both active volcanoes and volcanically not active areas, and is one of the few regions of the world where detailed mapping and quantification of the $\mathrm{CO}_{2}$ fluxes have been performed in the last two decades (CHIOdINI et alii, 1999; CHIODINI et alii, 2000; С HIOdIN et alii, 2004; Frondini et alii, 2008; FrondinI et alii, 2019). In particular, CHIODINI et alii (2004), based on the carbon balance of regional aquifers, produced the first regional map of $\mathrm{CO}_{2}$ degassing in central and southern Italy, showing the occurrence of two large scale $\mathrm{CO}_{2}$ anomalies on the Tyrrhenian (western) side of the Italian

(1) Istituto Nazionale di Geofisica e Vulcanologia, Sezione di Bologna, via D. Creti 12, 40128 Bologna, Italy.

(2) Dipartimento di Fisica e Geologia, Università degli Studi di Perugia, via Pascoli snc, 06123 Perugia, Italy.

(3) Istituto Nazionale di Geofisica e Vulcanologia, Sezione di Napoli Osservatorio Vesuviano, via Diocleziano 328, 80124 Napoli, Italy.

(4) Consiglio Nazionale delle Ricerche, Istituto di Ricerca per la Protezione Idrogeologica, via Madonna Alta 126, 06128 Perugia, Italy.

(5) Istituto Nazionale di Geofisica e Vulcanologia, Sezione di Pisa, via Cesare Battisti 53, 56125 Pisa, Italy.

(6) Agenzia Regionale per la Protezione Ambientale, ARPA Umbria, Via Pievaiola 207/B-3, 06132 Perugia, Italy.

(7) Geotecno S.R.L., Via Domenichino 49, 20149 Milano, Italy. Corresponding author e-mail: carlo.cardellini@unipg.it peninsula. The two structures, named Tuscan Roman Degassing Structure (TRDS) and Campanian Degassing Structure (CDS), discharge to the surface $1.69 \times 10^{4} \mathrm{t} \mathrm{d}^{-1}$ (i.e., 6.16 $\mathrm{Mt}^{-1}$ ) and $8.44 \times 10^{3} \mathrm{t} \mathrm{d}^{-1}$ (i.e., $3.08 \mathrm{Mt}^{-1}$ ) of $\mathrm{CO}_{2}$, respectively. The total amount of $\mathrm{CO}_{2}$ released to the atmosphere through diffuse regional degassing (9.24 $\left.\mathrm{Mt}^{-1}\right)$ is the main component of the geological $\mathrm{CO}_{2}$ budget in Italy, being higher than the amount of $\mathrm{CO}_{2}$ discharged by active Italian volcanoes $\left(7.32 \mathrm{Mt} \mathrm{y}^{-1}\right.$, FRONDINI et alii, 2019 and references therein). According to FrezzotTi et alii, (2009), the degassing process is related to decarbonation or melting, at pressure greater than 4 $\mathrm{GPa}(130 \mathrm{~km})$, of carbonate-rich lithologies subducted in the mantle.

In addition to $\mathrm{CO}_{2}$-rich groundwater, both TRDS and CDS are also characterized by the presence of many $\mathrm{CO}_{2}$ vents and areas of anomalous soil $\mathrm{CO}_{2}$ diffuse degassing (e.g., Chiodini et alii, 1999, 2007, 2011; RogIE et alii, 2000, www.magadb.net) that are generally fed by buried carbonate reservoirs, covered by low permeability formations, where the gas produced at depth accumulates before the expulsion to the surface (e.g., CHIodini et alii, 2007; Collettini et alii, 2008).

These gas emissions can represent a severe risk for humans and animals: at ambient temperature carbon dioxide is about 1.5 times heavier than air. During stable atmospheric conditions the gas can accumulate in topographic depressions reaching high, often lethal, concentrations (e.g., CHIODINI et alii, 2008; Costa et alii, 2008; ChIodini et alii, 2010).

The Bagni San Filippo hydrothermal system (BSF) is a paradigmatic example of the $\mathrm{CO}_{2}$ degassing process affecting western central Italy. $\mathrm{BSF}$ is located within TRDS, in the Mt. Amiata volcanic and geothermal area (AVGA, Fig. 1a). The degassing process at BSF results at the surface with focused gas vents, zones of diffuse soil $\mathrm{CO}_{2}$ degassing, $\mathrm{CO}_{2}$-rich thermal waters with temperatures from 23 to $48^{\circ} \mathrm{C}$ and large travertine deposits (FRONDINI et alii, 2009). The areas of stronger $\mathrm{CO}_{2}$ emission can be very dangerous both for humans and animals, as testified by a lethal accident occurred on November, 2003 in one of the topographic depressions of the area (Fig. 1b; https:// ricerca.gelocal.it/iltirreno/archivio/iltirreno/2003/11/20/ LF3PO LF302.html; CHIODINI et alii, 2008).

In this work, we combine i) the results of a detailed survey on the $\mathrm{CO}_{2}$ soil diffuse degassing, ii) a hydrogeochemical investigation of the BSF thermal waters, and iii) a study of the chemical and isotopic features of the gas emissions in order to derive a 

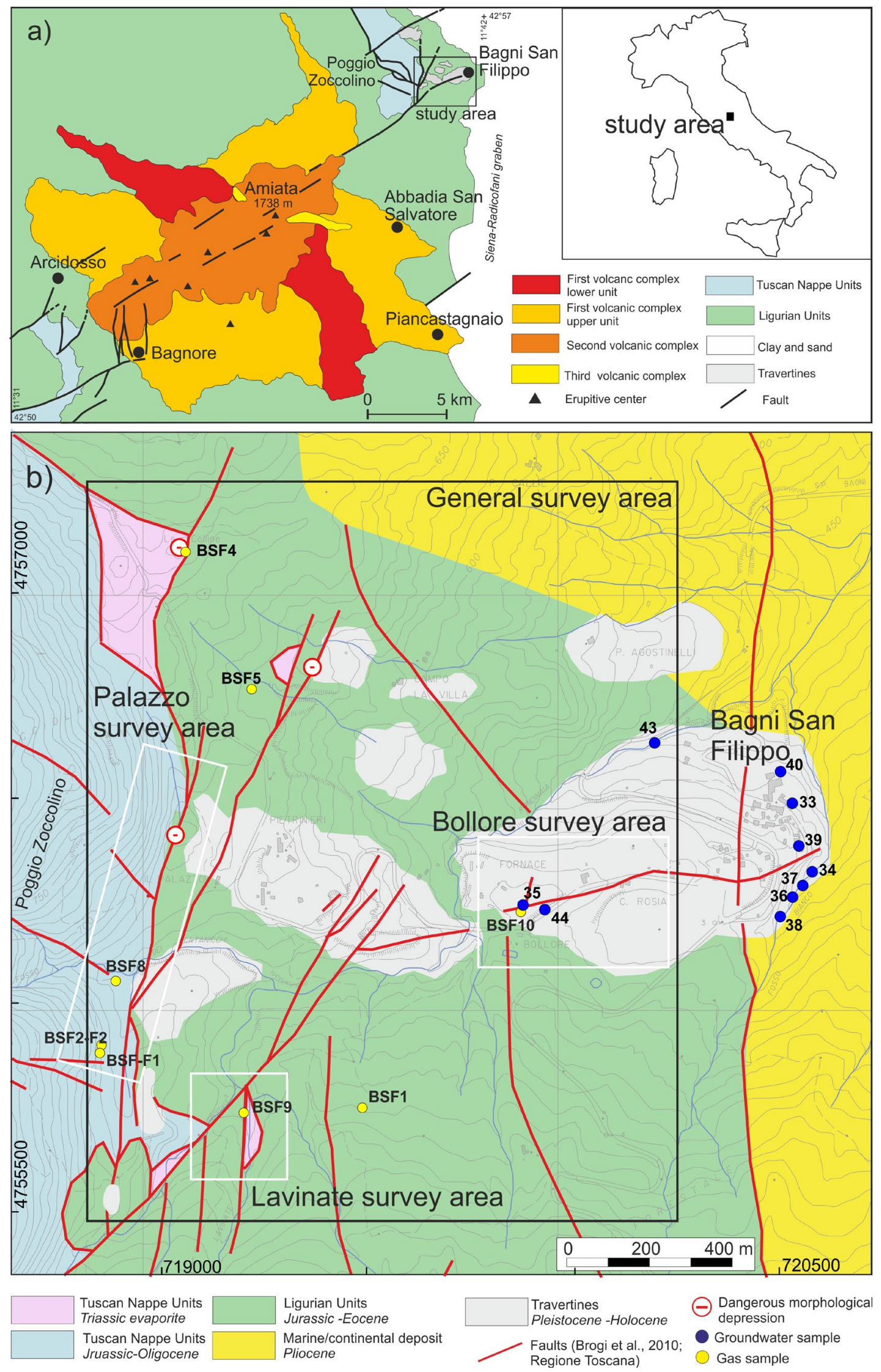

Fig. 1 - a) Simplified geological map of the Mt. Amiata volcanic and geothermal area (modified from BRogI et alii, 2010); b) Simplified geological map of Bagni San Filippo area (modified form Brogi et alii, 2010 and www502.regione.toscana.it/geoscopio/geologia.html) where are reported the location of sampled groundwaters, gas emissions and the areas of the $\mathrm{CO}_{2}$ flux surveys and the location of the morphological depressions where dangerous $\mathrm{CO}_{2}$ air concentrations occur. Coordinates are reported in ED50/UTM32N, EPSG:23032. 
comprehensive conceptual and quantitative model of the system. Besides this main aim, the definition of the most intensely degassing areas may contribute to mitigate the risk associated to the $\mathrm{CO}_{2}$ release.

The study is based on original data collected from December 2003 to May 2004, after the fatal accident of November 2003.

\section{GEOLOGICAL, GEOTHERMAL AND HYDROGEOLOGICAL SETTINGS.}

BSF is located in southern Tuscany (Italy), in the NE sector of the AVGA, on the western side of the SienaRadicofani graben (Fig.1a). The geological setting of the region is the result of the post-thickening evolution of the inner sector of the Northern Apennine, characterized by extensional processes accompanied by coeval magmatism active since early-middle-Miocene (e.g., CARMIGNANI et alii, 1995; Batini et alii, 2003; BRogi et alii, 2005; MARroni et alii, 2015a). During Cretaceous to early Miocene the study area was affected by compressional tectonics producing the stacking of the tectonic units belonging to the Northern Apennine paleogeographic domain (BROGI \& LIOTTA, 2006). Subsequently, from Miocene to present, the compressional structures were deformed by extensional tectonics producing the NNW-SSE basins (e.g., Siena-Radicofani graben), filled by marine to continental sediments, and the associated magmatism (FERRARI et alii, 1996; BRoGi et alii, 2005, 2015; BRogi \& LiotTA, 2006).

AVGA is characterized by the following tectonic stratigraphic units, from bottom to top: i) the Paleozoic crystalline metamorphic basement made up of graphitic phyllites, meta-sandstones, siltites, meta-carbonates and graphite-rich metasediments (Elter \& PANDELI, 1991). The formations of the basement are not exposed at the surface but have been drilled in the Piancastagnaio area (CHIODINI et alii, 1988; Elter \& PANDELI, 1991); ii) the Tuscan nappe, that includes sedimentary rocks ranging from Late Triassic evaporites to Jurassic carbonate platform, CretaceousOligocene pelagic sediments and late Oligocene-early Miocene turbidites (BROGI et alii, 2015; MARRONI et alii, 2015a); iii) the Sub-Ligurian and Ligurian Tectonic Units, composed by ophiolites, shales, sandstones, calcarenites and marls (PANDELI et alii, 2005; MARRONI et alii, 2015b); iv) the Neogene sedimentary deposits, mainly represented by sands and clays; v) the Mt. Amiata volcano, consisting on trachytic to olivine latitic lava flows and domes emplaced in a very short time between 305 and $231 \mathrm{ka}$ (FERRARI et alii, 1996; CONTICELLI et alii, 2015).

In the AVGA are present two water-dominated geothermal reservoirs sited in the southern part of the Amiata volcano. The shallower geothermal system is hosted by the carbonate-evaporite formations at depths of 500$1000 \mathrm{~m}$ and shows fluids with temperature ranging from 200 to $240{ }^{\circ} \mathrm{C}$, whereas the deeper one is localized in the metamorphic basal complex at depths of 2000-4500 $\mathrm{m}$ and temperatures between 300 and $350^{\circ} \mathrm{C}$ (CALAMAI et alii, 1970; BERTINI et alii, 1995). The geothermal reservoirs are tapped by the wells of two active geothermal fields (Piancastagnaio and Bagnore, Fig.1) with a total installed capacity of 121 $\mathrm{Mw}_{\mathrm{e}}$ (MANZELla et alii, 2019). The geothermal gradient of the area is generally between 80 and $150{ }^{\circ} \mathrm{C} \mathrm{km}^{-1}$ with local peaks up to $300{ }^{\circ} \mathrm{C} \mathrm{km}^{-1}$ (BALDI et alii, 1994) and the heat

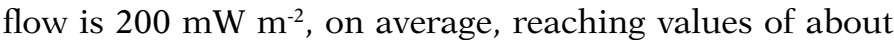
$600 \mathrm{~mW} \mathrm{~m}^{-2}$ in correspondence of the geothermal fields (CHIOdini et alii, 1988; BRogi et alii, 2005).

The hydrogeological setting of AVGA is dominated by a regional aquifer hosted by the Mesozoic carbonateevaporite formations of the Tuscan nappe and by a shallower aquifer hosted by fractured volcanic rocks (BoNI et alii, 1986; Chiodini et alii, 1988). The two aquifers are separated by a low permeability complex represented by Ligurian units and Neogene sediments, acting as an aquiclude. In AVGA the carbonate-evaporite aquifer is almost completely confined under the low permeability complex and is characterised by discontinuous recharge areas corresponding to the outcrops of the carbonateevaporite formations. On the southern and western side of Mt. Amiata the carbonate-evaporite structures represent the main geothermal reservoir and their lateral continuity permits the circulation of deep fluids over a large area (Celati et alii, 1990; Minissale et alii, 2002; Frondini et alii, 2009).

One of the few zones of AVGA where the Tuscan nappe sedimentary formations outcrop is the BSF area. In particular the carbonate and evaporite formations of the Tuscan Nappe outcrop on the western side of the study area (Mt. Poggio Zoccolino, Fig.1) while its western side is characterized by the Ligurian tectonic Units and its central part is characterized by Pliocene marine and continental deposits topped by a large Quaternary travertine plate, deposited by the thermal waters of the area. The aquifer hosted by the Tuscan Nappe, that is locally recharged by the Mt. Poggio Zoccolino (1035 $\mathrm{m}$ a.s.l.) structural high, discharge in the BSF area more than $35 \mathrm{~L} \mathrm{~s}^{-1}$ of thermal water with temperatures up to $48{ }^{\circ} \mathrm{C}$.

\section{METHODS}

A multi-parametric geochemical study of the BSF area was performed from December 2003 to May 2004. During this period the area was surveyed for the diffuse soil degassing of $\mathrm{CO}_{2}$, chemical and isotopic composition of gas discharged, chemical and isotopic composition of groundwater and chemical composition of the gas dissolved by groundwater.

\section{SOIL DIFFUSE DEGASSING}

From December 2003 to May 2004 four $\mathrm{CO}_{2}$ flux surveys were performed at BSF area using the accumulation chamber method (CHIOdini et alii, 1998), using a LI-800 infrared spectrometer as $\mathrm{CO}_{2}$ detector operating in the range 0-20000 ppm. During December 2003, an area of about $1.7 \mathrm{~km}^{2}$ (Fig. 1b) was investigated with 595 measurements of $\mathrm{CO}_{2}$ flux, homogeneously distributed and on average spaced $50 \mathrm{~m}$ (General survey, GS; Table 1). Based on the results of the GS data analysis, 3 detailed $\mathrm{CO}_{2}$ flux surveys were performed at Palazzo (PA), Lavinate (LA) and Bollore (BO) areas (Fig. 1b), by using a measurement spacing from 5 to $20 \mathrm{~m}$. In detail, $423 \mathrm{CO}$ flux measurements were performed at PA in March-April 2004, 325 at Lavinate in May 2004 and 303 at Bollore in March 2004 (Table 1). The complete datasets of the measured $\mathrm{CO}_{2}$ fluxes are reported in the Supplementary Material. 
TABLE 1

$\mathrm{CO}_{2}$ flux survey description and $\mathrm{CO}_{2}$ flux statistics.

\begin{tabular}{cccccc}
\hline Survey name & Date & N. points & $\begin{array}{c}\text { Surveyed area } \\
\left(\mathrm{m}^{2}\right)\end{array}$ & $\begin{array}{c}\text { Min. and max. } \mathrm{CO}_{2} \text { flux } \\
\left(\mathrm{g} \mathrm{m}^{-2} \mathrm{~d}^{-1}\right)\end{array}$ & $\begin{array}{c}\text { Mean } \mathrm{CO}_{2} \text { flux } \\
\left(\mathrm{g} \mathrm{m}^{-2} \mathrm{~d}^{-1}\right)\end{array}$ \\
\hline General survey (GS) & December 2003 & 595 & 1704150 & $0.56-72366$ & 534 \\
Palazzo survey (PA) & March-April 2004 & 423 & 69938 & $4.9-16212$ & 286 \\
Lavinate survey (LA) & May 2004 & 324 & 52500 & $5.8-110157$ & 1630 \\
Bollore survey (BO) & March 2004 & 303 & 76400 & $0.49-74021$ & 880 \\
\hline
\end{tabular}

The $\mathrm{CO}_{2}$ flux data were elaborated using both statistical and geostatistical tools. The graphical statistical method (GSA method, CHIODINI et alii, 1998), based on the Sinclair's partitioning method (SINCLAIR, 1974), was used to characterise the statistical distribution of the $\mathrm{CO}_{2}$ flux and the sources of the diffuse degassing. In fact, in volcanic and geothermal areas $\mathrm{CO}_{2}$ soil diffuse degassing is frequently fed by multiple gas sources, such as the biological and the deeply produced $\mathrm{CO}_{2}$. This multiple origin can result in a polymodal distribution of the $\mathrm{CO}_{2}$ flux, which plots on a log-probability plot as a curve with $n-1$ inflection points when $n$ lognormal populations overlap. Conversely, a single log-normal population would result in a "straight" line (SINCLAIR, 1974). The GSA allows to partition the polymodal distribution into individual log-normal populations and to estimate the relative proportion $\left(f_{i}\right)$ between different populations, their mean $\left(M_{i}\right)$ and standard deviation $\left(\sigma_{i}\right)$. Since the calculated $M_{i}$ refers to the logarithm of $\mathrm{CO}_{2}$ flux values, the mean of the $\mathrm{CO}_{2}$ flux was then estimated using a Monte Carlo simulation procedure. The uncertainty of this estimate is given in terms of $5^{\text {th }}$ and $95^{\text {th }}$ percentiles of the mean $\mathrm{CO}_{2}$ flux values returned by the Monte Carlo simulation.

A geostatistical approach based on the sequential Gaussian simulations (sGs method; CARDELLINI et alii, 2003) was used to map the diffuse $\mathrm{CO}_{2}$ degassing and to quantify the total $\mathrm{CO}_{2}$ output when possible. The sGs method consists of the production of numerous equiprobable realizations of the spatial distribution of the $\mathrm{CO}_{2}$ flux, here performed using the sgsim algorithm of the GSLIB software library (Deutsch \& Journel, 1998). The $\mathrm{CO}_{2}$ flux is simulated on a regular grid, according to the variogram model defined fitting the experimental variogram of the normal scores of the $\mathrm{CO}_{2}$ flux, which provides a description of how the data are spatially correlated. The variogram model is given in terms of nugget, range and sill parameters, where the nugget represents the small-scale variability, the range represents the distance within which data are correlated and the sill is the plateau the variogram reaches for a distance equal to the range. The produced realizations were then used to draw the maps of the $\mathrm{CO}_{2}$ diffuse degassing, which are here provided as probability maps. The probability map consists of a map of the probability that, among all the realizations, the simulated $\mathrm{CO}_{2}$ flux at any location (i.e., at grid nodes) is above a cut-off value. Selecting the threshold value of the biogenic $\mathrm{CO}_{2}$ flux as a cut-off, the probability map is used to highlight the area interested by the emission of deeply derived $\mathrm{CO}_{2}$ (i.e., the diffuse degassing structure, DDS; CHIOdINI et alii, 2001, CARDELlini et alii, 2003). According to CARDELLINI et alii (2003), the DDS is here considered as the area where the probability that the simulated $\mathrm{CO}_{2}$ flux is higher than the biogenic $\mathrm{CO}_{2}$ flux threshold is over $50 \%$.
The total $\mathrm{CO}_{2}$ output is defined for each area as the mean of the total $\mathrm{CO}_{2}$ output computed for each realization, which is computed by summing the products of the simulated $\mathrm{CO}_{2}$ flux value at each grid cell by the cell surface. The uncertainty of the estimate is assessed from the $5^{\text {th }}$ and $95^{\text {th }}$ percentiles of the total $\mathrm{CO}_{2}$ output values computed for all the realizations.

\section{GROUNDWATER AND GAS EMISSIONS SAMPLING AND ANALYSES}

Ten springs, representing the main thermal groundwater outflows of BSF, were sampled in February 2004. Location of sampling points is shown in Fig. 1b. For each water sample, temperature, $\mathrm{pH}, \mathrm{Eh}$, electrical conductivity and $\mathrm{HCO}_{3}$ were measured in the field. $\mathrm{HCO}_{3}$ concentration was determined by acid titration with $0.01 \mathrm{~N} \mathrm{HCl}$ using methyl orange as indicator. Water samples for chemical and isotopic ( $\delta \mathrm{D}$ and $\delta^{18} \mathrm{O}$ ) analyses were collected in $100 \mathrm{~mL}$ and $250 \mathrm{~mL}$ HDPE (high-density polyethylene) bottles. One of the $100 \mathrm{~mL}$ aliquots was filtered upon sampling through $0.45 \mu \mathrm{m}$ membrane filters and then acidified with $1 \%$ of 1:1 diluted $\mathrm{HCl}$. Water samples for isotopic composition of total dissolved inorganic carbon (TDIC) were collected in $1000 \mathrm{~mL}$ glass bottles. The dissolved carbon species were precipitated directly in the field as $\mathrm{SrCO}_{3}$ by adding $\mathrm{SrCl}_{2}$ and $\mathrm{NaOH}$ in solid state to the water sample. Carbonate precipitate was recovered by filtering the sample and washed with distilled water in a $\mathrm{CO}_{2}$-free atmosphere in the laboratory. Carbon isotopic analyses of the TDIC $\left(\delta^{13} \mathrm{C}_{\mathrm{TDIC}}\right)$ were performed on the $\mathrm{CO}_{2}$ gas liberated from the $\mathrm{SrCO}_{3}$ precipitate by reaction with $100 \% \mathrm{H}_{3} \mathrm{PO}_{4}$.

Major ions were determined at the laboratory of Perugia University. Calcium and $\mathrm{Mg}$ concentrations were determined by atomic absorption (AA) flame spectroscopy on the acidified sample while $\mathrm{Na}$ and $\mathrm{K}$ were determined by atomic emission (AE) flame spectroscopy, using an Instrumentation Laboratory aa/ae spectrophotometer 951. $\mathrm{Cl}$ and $\mathrm{SO}_{4}$ were determined by ion chromatography using a Dionex DX-120.

Carbon, oxygen and hydrogen isotopes analyses were performed at the Geochemistry Laboratory of INGV-Naples using a Finnigan Delta plusXP continuous flow mass spectrometer coupled with GasbenchII device. Isotopic compositions are given in $\delta \%$ notation per mill versus V-PDB for carbon and versus V-SMOW for hydrogen and oxygen (analytical errors are: $\delta \mathrm{D} \pm 1 \% \circ, \delta^{18} \mathrm{O} \pm 0.08 \% \circ$ and $\delta^{13} \mathrm{C} \pm 0.06 \%$ )

The main accessible gas emissions were sampled in November 2003 and February 2004 (Fig. 1b). Two samples were collected at each sampling site using a $50 \mathrm{~mL}$ and a 
$250 \mathrm{~mL}$ glass vials, both equipped with a Teflon stopcock fixed with a rubber O-ring. The $250 \mathrm{ml}$ glass vials were pre-evacuated and filled with about $50 \mathrm{ml}$ of a $4 \mathrm{~N} \mathrm{NaOH}$ solution (GiggenBach, 1975; GiggenBach \& Goguel, 1989). Chemical analysis of gas samples were performed at the Geochemistry Laboratory of INGV-Naples.

Carbon dioxide and sulphur species, absorbed in the $\mathrm{NaOH}$ solution in the vial, were analysed after oxidation with $\mathrm{H}_{2} \mathrm{O}_{2}$, by acid-base titration and by ion-chromatography, respectively. The gas species not absorbed by the $\mathrm{NaOH}$ solution (i.e., $\mathrm{He}, \mathrm{Ar}, \mathrm{O}_{2}, \mathrm{~N}_{2}, \mathrm{H}_{2}$, and $\mathrm{CH}_{4}$ ) present in the vial headspace, were analysed using a gaschromatograph (Agilent Technologies 6890N), make up of two channels

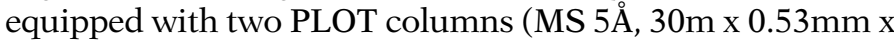
$50 \mu \mathrm{m}$; He and Ar as carrier gas) and Thermal Conductivity Detectors (TCD). Carbon monoxide was determined on the $50 \mathrm{~mL}$ dry gas sample by means of gas-chromatographic separation (Agilent Technologies 6890N) with a PLOT column MS $5 \AA 30 \mathrm{~m}$ x $0.53 \mathrm{~mm}$ x $50 \mu \mathrm{m}$ (He as carrier gas) using a high-sensitivity reduced gas detector (Trace Analytical RGD2; detection limit 0.05 ppm).

The isotopic composition of $\mathrm{CO}_{2}$ was determined on 50 $\mathrm{mL}$ dry gas sample by the same instrumentation used for $\delta^{13} \mathrm{C}_{\text {TDIC }}$ analyses

\section{RESULTS AND DISCUSSION}

$\mathrm{CO}_{2}$ DIFFUSE DEGASSING

\section{General survey (GS)}

The measured $\mathrm{CO}_{2}$ flux in the GS survey (Fig. 2) varies of orders of magnitude from a minimum of $\sim 0.5 \mathrm{~g} \mathrm{~m}^{-2}$ $\mathrm{d}^{-1}$ to $\sim 70,000 \mathrm{~g} \mathrm{~m}^{-2} \mathrm{~d}^{-1}$ (average value of $533 \mathrm{~g} \mathrm{~m}^{-2} \mathrm{~d}^{-1}$ ). The high $\mathrm{CO}_{2}$ fluxes (i.e., higher than 200-300 $\mathrm{g} \mathrm{m}^{-2} \mathrm{~d}^{-1}$ ) are strongly variable, represent a relatively low proportion of the entire dataset $(\sim 5 \%)$ (Fig. 3a) and are generally located nearby the main gas vents (Fig. 2).

The probability plot (Fig. 3a) shows that the statistical distribution of the $\mathrm{CO}_{2}$ flux is the result of the overlapping of 2 log-normal $\mathrm{CO}_{2}$ flux populations. For the low flux population (low flux population general survey, LFP-GS, Table 2) we compute a mean value of $9.4 \mathrm{~g} \mathrm{~m}^{-2} \mathrm{~d}^{-1}(8.8-$ $10.0 \mathrm{~g} \mathrm{~m}^{-2} \mathrm{~d}^{-1}$ ) while for the high flux population (high flux population general survey HFP-GS) the Monte Carlo approach returns a mean value of $\sim 14000 \mathrm{~g} \mathrm{~m}^{-2} \mathrm{~d}^{-1}$ with a very large variability of the estimation $\left(2000-41000 \mathrm{~g} \mathrm{~m}^{-2}\right.$ $\left.\mathrm{d}^{-1}\right)$. Such high fluxes are clearly fed by a $\mathrm{CO}_{2}$ deep source. On contrary the mean flux of LFP-GS well falls within the range of the $\mathrm{CO}_{2}$ fluxes produced by the biological activity

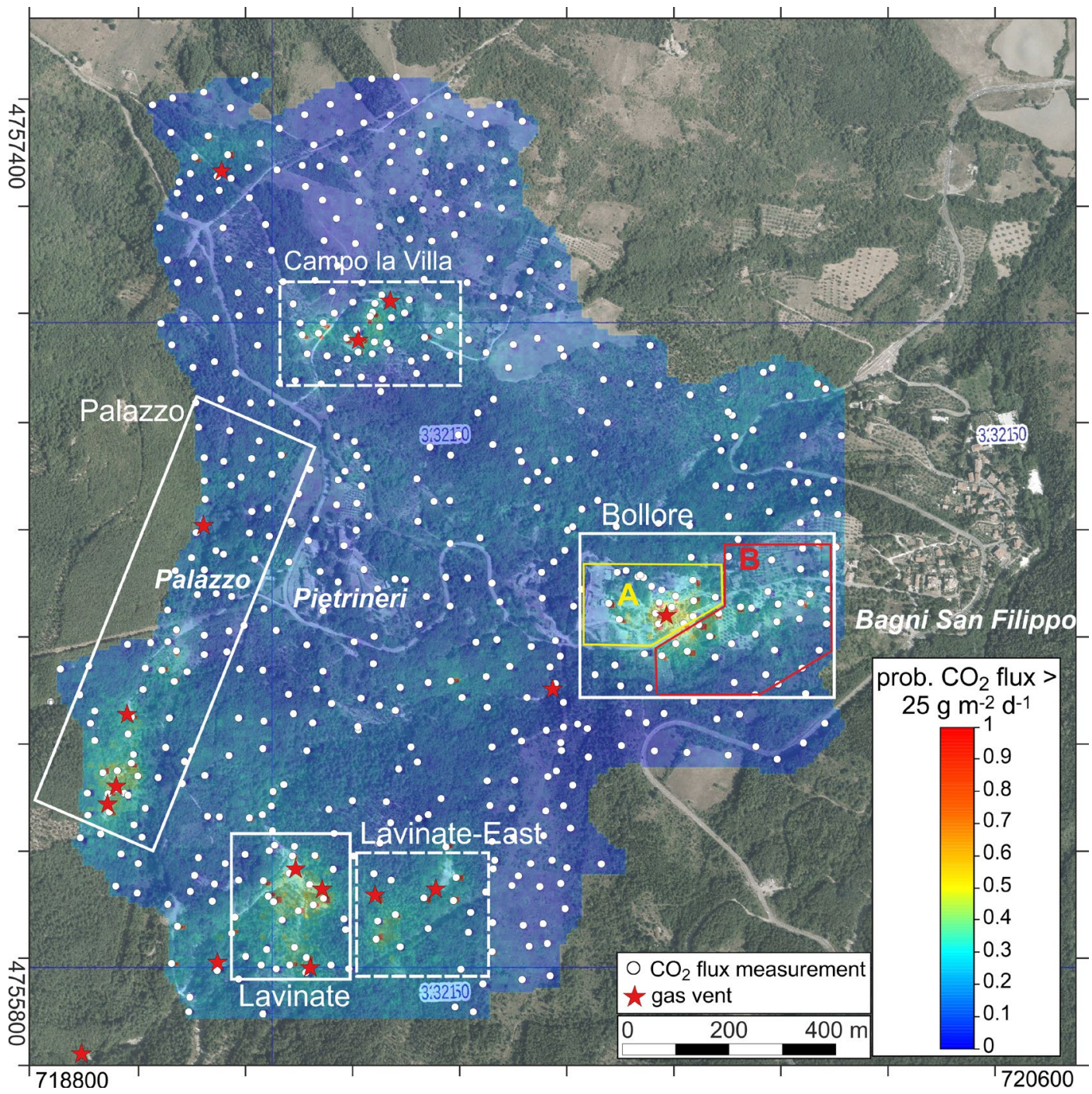

Fig. 2 - Location of the $\mathrm{CO}$ flux measurements of the GS survey and diffuse $\mathrm{CO}_{2}$ degassing map. In the map are also reported: i) the areas of the detailed survey (Bollore survey, Lavinate survey and Palazzo survey; solid line boxes); ii) the two sectors of Bollore area considered in the text (A and B); iii) the two areas where the $\mathrm{CO}_{2}$ output was estimated by the GS dataset (Campo la Villa and Lavinate-East; dashed line boxes). The red stars correspond to gas emission site ( $\mathrm{CO}_{2}$-rich vents) from this study and from MaGa database (www.magadb.net) Coordinates are reported in ED50/UTM32N, EPSG:23032. 

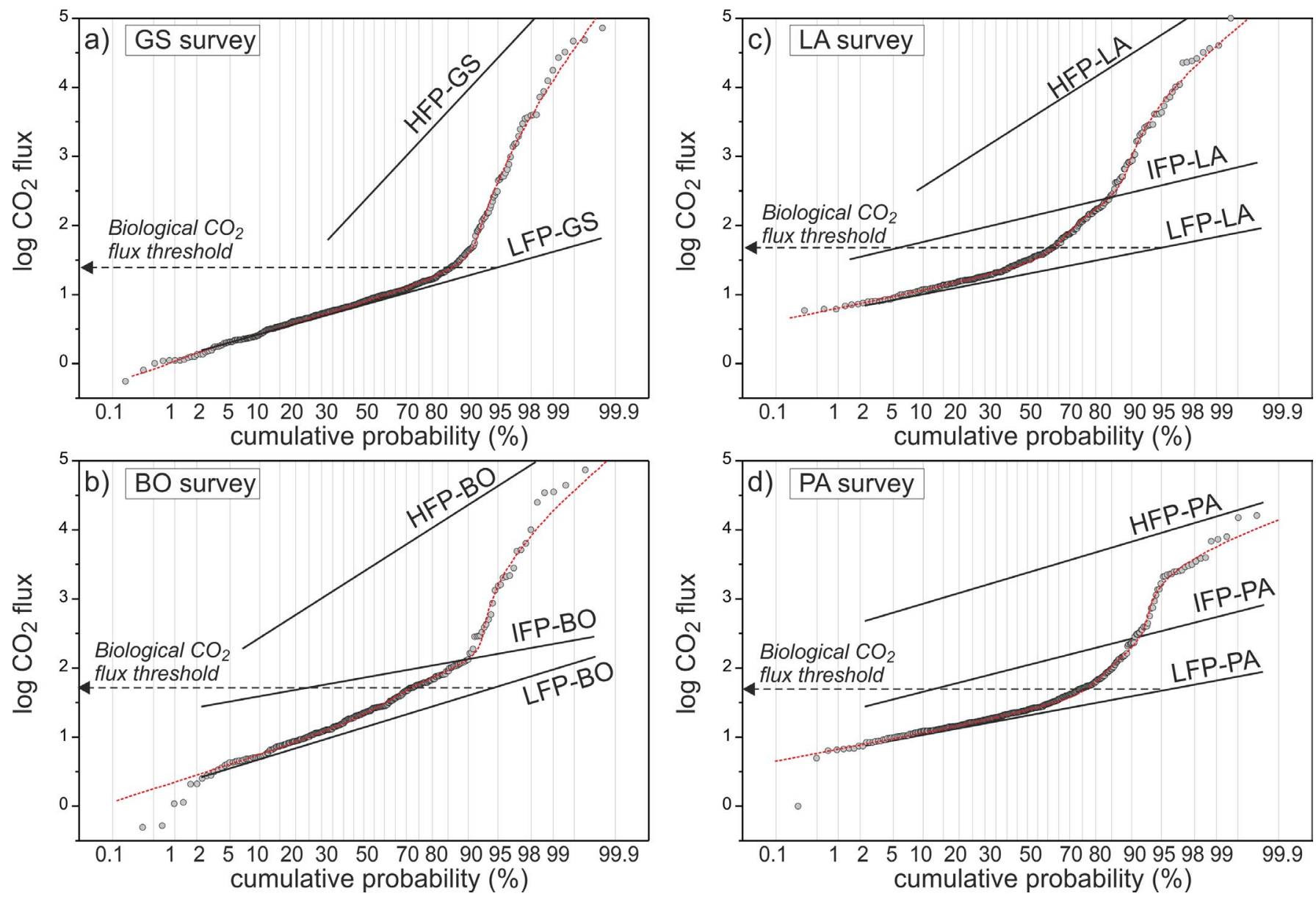

Fig. 3 - Probability plot of $\mathrm{CO}_{2}$ flux from a) general survey, b) Bollore survey, c) Lavinate survey and d) Palazzo survey. The black lines represent the partitioned population while the dashed red lines represent the combination of the partitioned populations according to their relative proportions (see Table 2).

\section{TABLE 2}

Statistical parameters of the individual populations partitioned for each dataset.

\begin{tabular}{|c|c|c|c|c|c|}
\hline Populations & $\begin{array}{c}\text { Mean } \\
\log \mathrm{CO}_{2} \text { flux }\end{array}$ & $\begin{array}{c}\sigma \\
\log \mathrm{CO}_{2} \text { flux }\end{array}$ & $f$ & $\begin{array}{c}\text { Mean } \mathrm{CO}_{2} \text { flux } \\
\left(\mathrm{g} \mathrm{m}^{-2} \mathrm{~d}^{-1}\right)\end{array}$ & $\begin{array}{c}95^{\text {th }} \text { percentile } \\
\left(\mathrm{g} \mathrm{m} \mathrm{m}^{-2} \mathrm{~d}^{-1}\right)\end{array}$ \\
\hline \multicolumn{6}{|c|}{ General survey } \\
\hline LFP-GS & 0.85 & 0.33 & 0.88 & $9.4(8.8-10.0)$ & 24.7 \\
\hline HFP-GS & 2.35 & 1.26 & 0.12 & $14025(2169-41120)$ & 26466 \\
\hline \multicolumn{6}{|c|}{ Palazzo survey } \\
\hline LFP-PA & 1.31 & 0.218 & 0.78 & $23.1(22.1-24.3)$ & 46.6 \\
\hline IFP-PA & 2.04 & 0.3 & 0.15 & $139(118-162)$ & 341 \\
\hline HFP-PA & 3.38 & 0.35 & 0.07 & $3311(2436-4359)$ & 9031 \\
\hline \multicolumn{6}{|c|}{ Lavinate survey } \\
\hline LFP-LA & 1.3 & 0.23 & 0.65 & $22.9(21.5-24.4)$ & 47.7 \\
\hline IFP-LA & 2.12 & 0.28 & 0.22 & $162(141-186)$ & 380 \\
\hline HFP-LA & 3.523 & 0.75 & 0.13 & 14925 (6604-28484) & 57115 \\
\hline \multicolumn{6}{|c|}{ Bollore survey } \\
\hline LFP-BO & 1.138 & 0.36 & 0.71 & $19.4(17.3-21.5)$ & 53.7 \\
\hline IFP-BO & 1.86 & 0.21 & 0.21 & $81(73-90)$ & 160 \\
\hline HFP-BO & 3.4 & 0.75 & 0.08 & $11145(3893-25426)$ & 43028 \\
\hline
\end{tabular}

*between brackets are reported the $5^{\text {th }}$ and $95^{\text {th }}$ percentile of the mean $\mathrm{CO}_{2}$ flux values returned by the Monte Carlo simulation procedure. 
in the soil in a wide variety of ecosystems (mean $\mathrm{CO}_{2}$ flux from $0.2 \mathrm{~g} \mathrm{~m}^{-2} \mathrm{~d}^{-1}$ to $21 \mathrm{~g} \mathrm{~m}^{-2} \mathrm{~d}^{-1}$, CARDELlinI et alii, 2017; VIVEIROs et alii, 2010 and reference therein). For this reason the LFP-GS population can be considered as representative of the biological $\mathrm{CO}_{2}$ flux for the period of the GS.

The variogram of the normal scores of the $\mathrm{CO}_{2}$ flux of the GS shows a high nugget value ( 0.75 , Fig. $4 \mathrm{a})$ suggesting that the $\mathrm{CO}_{2}$ flux has a large spatial variability at a scale smaller than the spacing between the measurements. This is possibly due to the low permeability of the soils that forces the gas to flow mainly through fractures.

A total deep $\mathrm{CO}_{2}$ output of $849 \mathrm{t} \mathrm{d}^{-1}$ was computed for the GS survey (Table 3 ) by subtracting to the total $\mathrm{CO}_{2}$ output estimated by sGs approach $\left(865 \mathrm{t} \mathrm{d}^{-1}\right.$, see Methods) the biological $\mathrm{CO}_{2}$ contribution of $9.4 \mathrm{~g} \mathrm{~m}^{-2} \mathrm{~d}^{-1}$ (Table 2). However, the reliability of this estimate is low because the high small-scale spatial variability of the $\mathrm{CO}_{2}$ fluxes, in comparison to the spacing between the measurements. As already noted in other areas, a large measurement spacing of highly spatially variable soil $\mathrm{CO}_{2}$ fluxes can in fact cause an overestimation of the total $\mathrm{CO}_{2}$ output (e.g., VIVEIROs et alii, 2010) and/or a large uncertainty of the estimate (CARDELLINI et alii, 2003).

In order to have more reliable estimations, we decided to perform detailed surveys of the most anomalous zones. We selected the anomalous areas of Bollore (BO), Palazzo
(PA) and Lavinate (LA) based on the $\mathrm{CO}_{2}$ flux probability map (Fig. 2) which has been drawn assuming a $\mathrm{CO}_{2}$ flux cut-off value of $25 \mathrm{~g} \mathrm{~m}^{-2} \mathrm{~d}^{-1}$ (i.e., the $95^{\text {th }}$ percentile of the LFP-GS population, Fig. 3a).

\section{Detailed surveys (BO, PA, LA)}

The measured $\mathrm{CO}_{2}$ fluxes of the detailed surveys distribute from few $\mathrm{g} \mathrm{m}^{-2} \mathrm{~d}^{-1}$ to more than $100000 \mathrm{~g} \mathrm{~m}^{-2}$ $\mathrm{d}^{-1}$, similar to that of the GS (Table 1). For all the three surveys the probability distribution of $\mathrm{CO}_{2}$ fluxes is interpreted as the results of the overlapping of three $\mathrm{CO}_{2}$ flux populations (Fig. 3b-d). The populations with the lowest mean $\mathrm{CO}_{2}$ fluxes are characterised by very similar and reliably estimated mean values: $23.1 \mathrm{~g} \mathrm{~m}^{-2} \mathrm{~d}^{-1}, 22.9 \mathrm{~g}$ $\mathrm{m}^{-2} \mathrm{~d}^{-1}$ and $19.4 \mathrm{~g} \mathrm{~m}^{-2} \mathrm{~d}^{-1}$ for LFP-PA, LFP-LA and LFO-BO, respectively (Table 2 ). These values are our best estimate of the biogenic $\mathrm{CO}_{2}$ contribution that in any area resulted higher than the biological background $\mathrm{CO}_{2}$ flux for the GS survey $\left(9.4 \mathrm{~g} \mathrm{~m}^{-2} \mathrm{~d}^{-1}\right)$, likely because the different season of the surveys (the GS was performed during the winter while PA, LA and BO surveys were performed during the spring). The biological soil $\mathrm{CO}_{2}$ flux in fact varies with the environmental conditions (e.g., air/soil temperature, precipitation and soil water content) and is generally
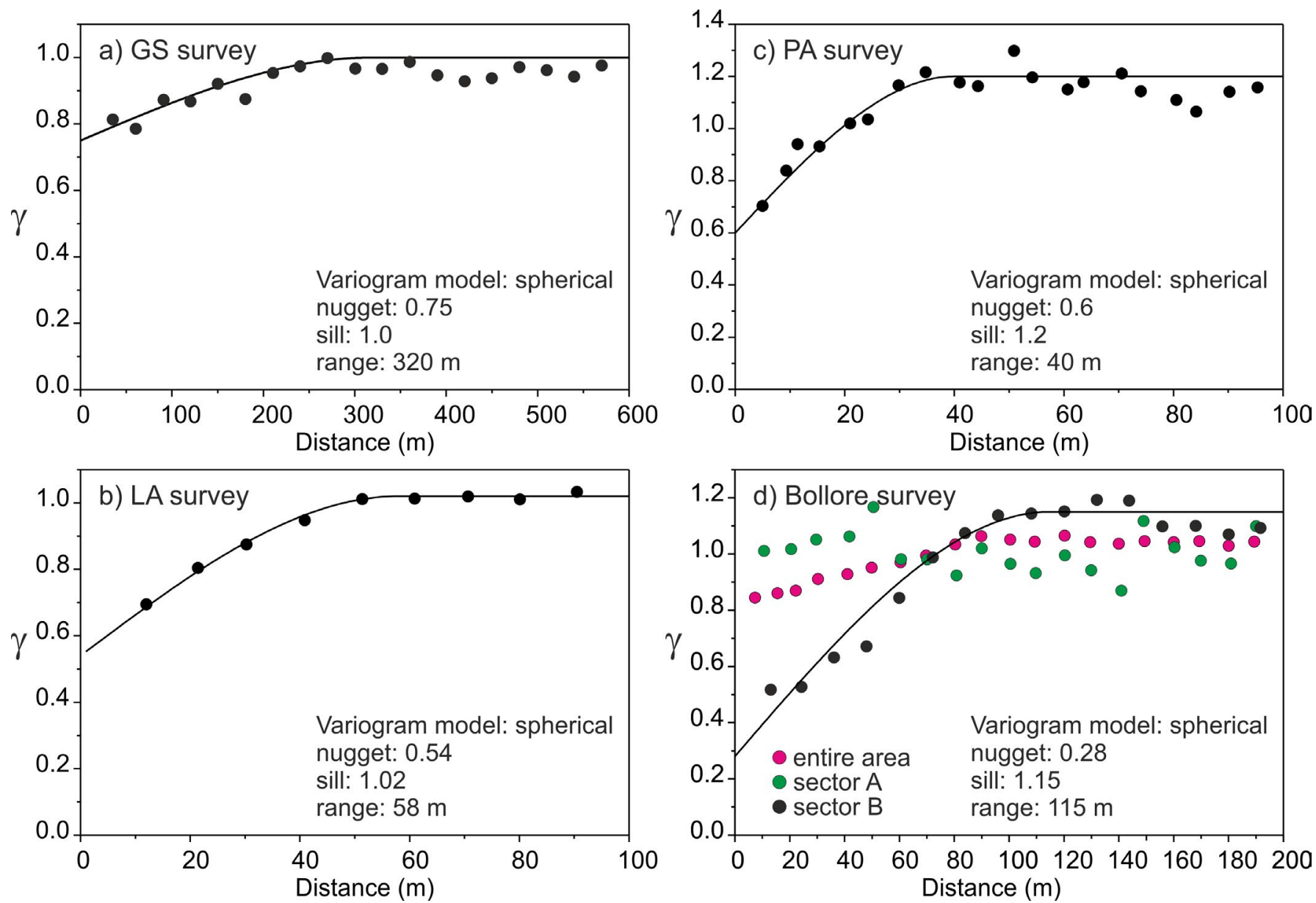

Fig. 4 - Experimental variogram of the $\mathrm{CO}_{2}$ flux normal scores and variogram models for a) general survey, b) Lavinate survey, c) Palazzo survey and d) Bollore survey. For this latter survey are also reported the variograms computed considering two subsets of data: sector A and sector B (see Fig. 2 and the text for explanations). 
TABLE 3

Total and deep $\mathrm{CO}_{2}$ output estimates.

\begin{tabular}{lcccc}
\hline Survey name & $\begin{array}{c}\text { Area } \\
\left(\mathrm{m}^{2}\right)\end{array}$ & $\begin{array}{c}\text { Total } \mathrm{CO}_{2} \text { output } \\
\left(\mathrm{t} \mathrm{d}^{-1}\right)\end{array}$ & $\begin{array}{c}\text { Deep } \mathrm{CO}_{2} \text { output } \\
\left(\mathrm{t} \mathrm{d}^{-1}\right)\end{array}$ & $\begin{array}{c}\text { Deep } \mathrm{CO}_{2} \text { output } \\
5^{\text {th }}-95^{\text {th }} \text { percentile } \\
\left(\mathrm{t} \mathrm{d}^{-1}\right)\end{array}$ \\
\hline General (GS) & 1704150 & 865 & 849 & $736-1010$ \\
Palazzo (PA) & 69938 & 21.4 & 19.8 & $17.9-25.2$ \\
Lavinate (LA) & 52500 & 65.0 & 63.8 & $51.6-80.0$ \\
Bollore (BO) & 96186 & 48.2 & 47.0 & $19.1-101$ \\
Bollore sector A & 36250 & $41.6^{*}$ & $41.6^{*}$ & $16.1-87.7^{*}$ \\
Bollore sector B & 59936 & 6.6 & 5.4 & $3.0-13.5$ \\
\hline
\end{tabular}

*estimated by GSA method.

higher in the spring-summer when can be up to of 4-5 times higher respect to the winter (e.g., Davinson et alii, 1998; RaIch \& SCHLEsinger, 1992). The deeply derived CO $_{2}$ flux is clearly identified by the other two populations, HFP and IFP (intermediate flux population), which in each survey are both characterized by a mean $\mathrm{CO}_{2}$ flux too high for the biogenic source (Table 2). The presence of two deeply derived $\mathrm{CO}_{2}$ flux populations could reflect the relative prevalence of diffusive or advective $\mathrm{CO}_{2}$ transport mechanisms.

The computation of the $\mathrm{CO}_{2}$ output from the detailed surveys was computed, when possible, using the sGs approach that is based on the spatial correlations among the measurements. The variograms of the LA and PA surveys dataset (Fig. 4b, c) show nugget effect (0.6 and $0.54)$ lower than that of the GS variogram model $(0.75)$ indicating that the spacing between the measurements of the detailed surveys (smaller than that used in the GS) is more adequate to catch the spatial structure of the $\mathrm{CO}_{2}$ flux. Conversely, for the BO survey, even if a relatively high measurements density was used, the experimental variogram shows a high nugget component (higher than 0.8 ) suggesting a strong small-scale variability of the $\mathrm{CO}_{2}$ flux. This variability is particularly strong in the NE sector of the surveyed area (sector A, Fig. 2) as suggested by the "pure nugget effect" variogram of $\mathrm{CO}_{2}$ fluxes measured in this area Fig. 4d) which indicates the lack of any spatial correction. Sector A is in fact dominated by the presence of a hill made of travertine whit null or scarce soil, and the $\mathrm{CO}_{2}$ mainly flow through fractures resulting in a variability of the flux of orders of magnitude at a very small scale. Contrariwise, the variogram of sector B (i.e., the remaining BO area, sector B in Fig. 2) shows a relatively low nugget (Fig. 4d).

The $\mathrm{CO}_{2}$ flux was mapped by sGs for LA, PA and only for the sector B of BO performing 200 simulations for each area (using $2 \mathrm{~m} \times 2 \mathrm{~m}$ cells) and are reported in Fig. 5 as probability maps. At Palazzo the $\mathrm{CO}_{2}$ flux map (Fig. 5a) highlights the presence of a series of DDSs roughly distributed along a NNE-SSW band, a direction coincident with the orientation of the fault bordering Mt. Poggio Zoccolino (Fig 1b). A fault damage zone interested by a strong $\mathrm{CO}_{2}$ degassing is evident in the southern part of the area and along the NNE-SSW direction are located numerous $\mathrm{CO}_{2}$ vents and a large morphological depression (Fig. 5a) where a strong $\mathrm{CO}_{2}$ vent at its bottom causes high $\mathrm{CO}_{2}$ air concentrations (up to $50 \%$ vol $\mathrm{CO}_{2}$ was measured during the survey). At Lavinate the $\mathrm{CO}_{2}$ flux map shows a well-defined DDS that mainly develops along the creeks directions (e.g., Torrente Lavinate and Fosso Rondinaia, Fig. 5b) which follow the directions of the main faults (Fig. 1b). In particular, the NE-SW direction corresponds to Bagni San Filippo Fault which represents the prosecution of the Mt. Amiata fault along which developed the main volcanic centres (Brogi \& FabBrinI, 2009, Brogi et alii, 2010). For the sector B of Bollore the $\mathrm{CO}_{2}$ flux map (Fig. 5c) highlights a roughly E-W elongated DDS in continuity with the orientation of the travertine hill, where the highest fluxes were measured. All these features of the $\mathrm{CO}_{2}$ degassing suggest the main role of the tectonic structures on the upward transfer of the deeply produced $\mathrm{CO}_{2}$.

Based on the sGs results, the total $\mathrm{CO}_{2}$ output was computed for PA, LA and BO sector B resulting in $21.4 \mathrm{t}$ $\mathrm{d}^{-1}, 65 \mathrm{t} \mathrm{d}^{-1}$ and $6.6 \mathrm{t} \mathrm{d}^{-1}$ respectively (Table 3 ). The deep $\mathrm{CO}_{2}$ output was then estimated subtracting the biological $\mathrm{CO}_{2}$ contribution (i.e., the mean $\mathrm{CO}_{2}$ flux of the respective LFP populations) to the total $\mathrm{CO}_{2}$ output and results of $19.8 \mathrm{t} \mathrm{d}^{-1}, 63.8 \mathrm{t} \mathrm{d}^{-1}$ and $5.4 \mathrm{t} \mathrm{d}^{-1}$ for PA, LA and BO sector $\mathrm{B}$ respectively (Table 3 ). For sector A of $\mathrm{BO}$ the total deep $\mathrm{CO}_{2}$ output was estimated by the GSA method (CHIODINI et alii, 1998) because of the lack of spatial correlation among the measured fluxes. Summing the estimates for the two sectors (Table 3), a total deep $\mathrm{CO}_{2}$ output of $47 \mathrm{t} \mathrm{d}^{-1}$ is obtained for the entire Bollore area.

\section{Total $\mathrm{CO}_{2}$ output from BSF}

The total deep $\mathrm{CO}_{2}$ output from the BSF area is computed by summing the above BO, PA and LA results $\left(130 \mathrm{t} \mathrm{d}^{-1}\right)$ to the flux estimated for other two degassing areas not measured in detail, i.e. Campo la Villa (CLV) and Lavinate-East (LE) (Fig. 2). For these two areas, rough estimations were obtained by the sGs applied to the GS data multiplied by an empirical correction factor $(c f)$ estimated as the ratio between the results of the detailed campaigns at BO, PA and LA and the results over the same areas using the GS data. The GS estimates are systematically higher than those of the detailed surveys and the $c$ varies from 0.3 to 0.85 . Using these values, the cumulative contribution of deeply derived $\mathrm{CO}_{2}$ from CLV and LE results at $30 \mathrm{t}$ $\mathrm{d}^{-1}$ to $80 \mathrm{t} \mathrm{d}^{-1}$. Therefore, our best estimation of the total deep $\mathrm{CO}_{2}$ output diffusively emitted at BSF is of $160-210$ $\mathrm{t} \mathrm{d}^{-1}$. This value is the highest among the measured gas manifestations of AVGA including Selvena $\left(17 \mathrm{t} \mathrm{d}^{-1}\right.$; RogIE 

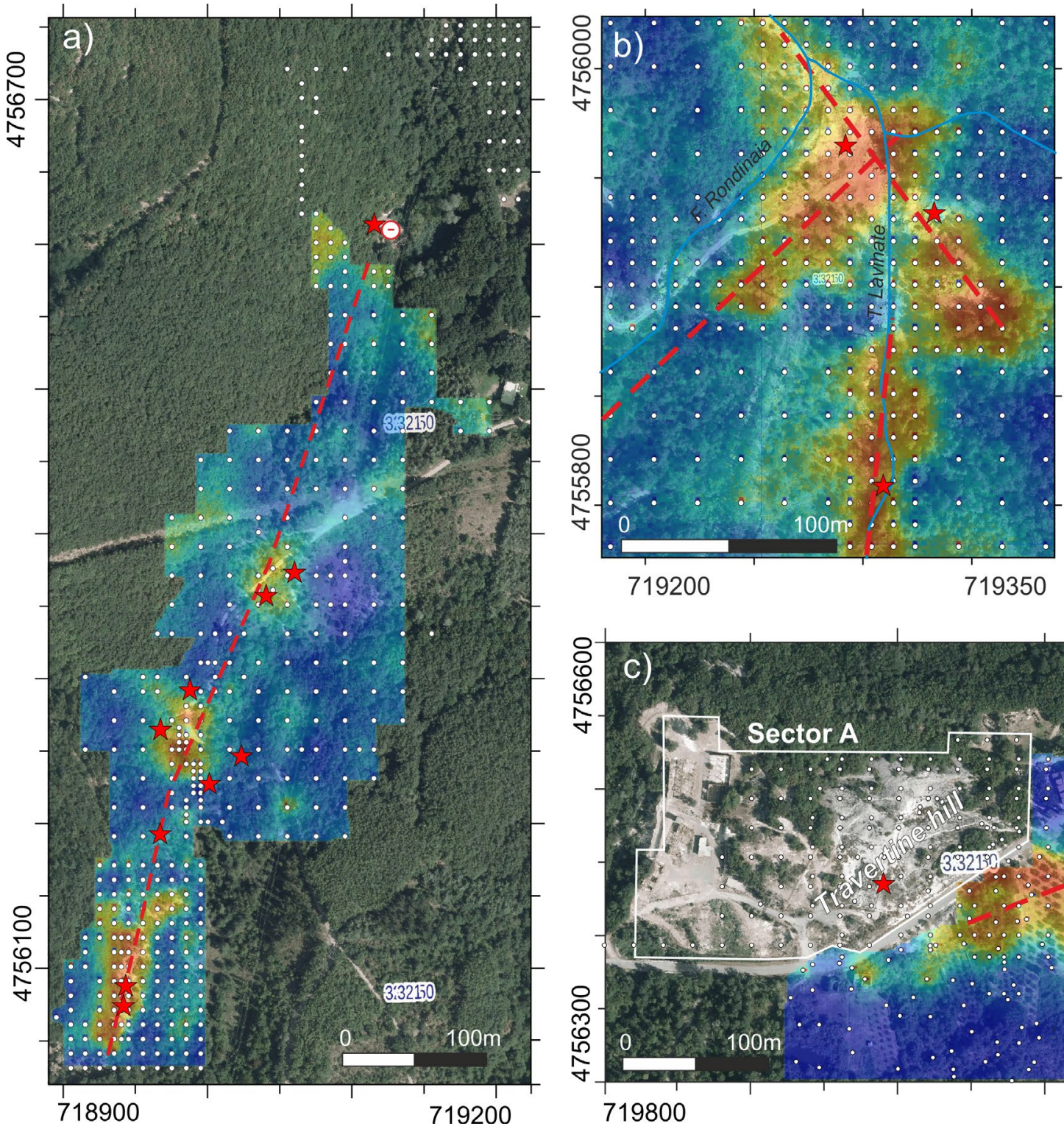

prob. $\mathrm{CO}_{2}$ flux $>$

$50 \mathrm{~g} \mathrm{~m}_{1}^{-2} \mathrm{~d}^{-1}$

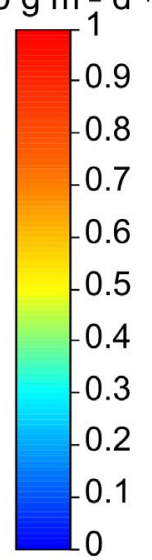

- $\mathrm{CO}_{2}$ flux measurement

- inferred fault

$\star \mathrm{CO}_{2}$ vent

$\odot$ Dangerous morphological depression

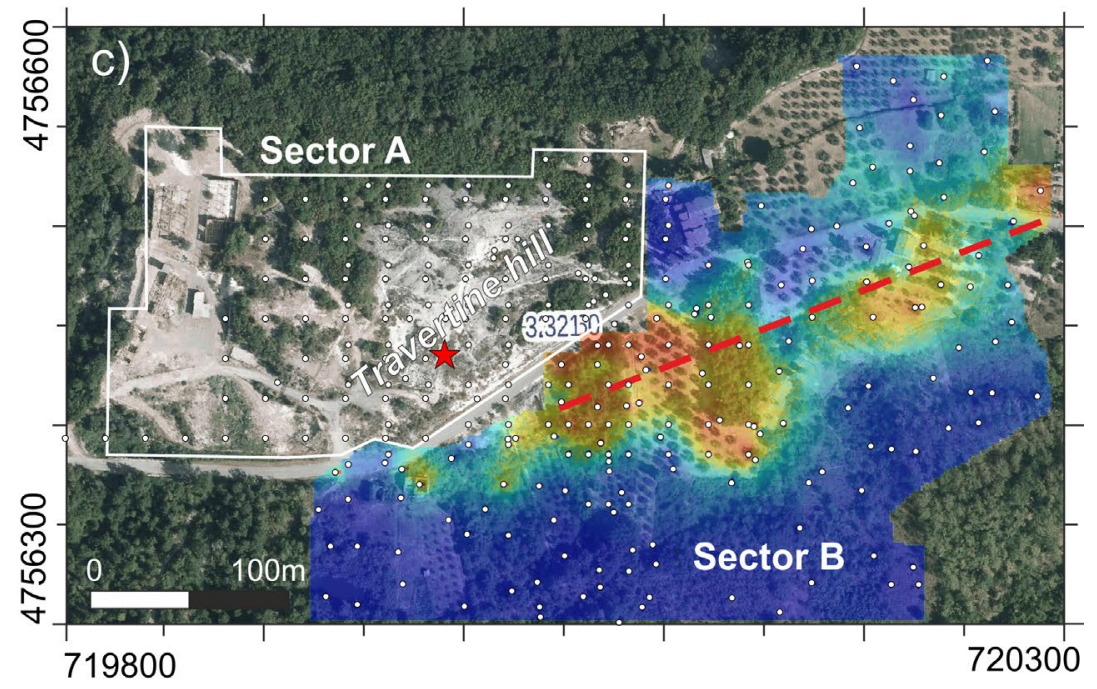

Fig. 5 - Diffuse $\mathrm{CO}_{2}$ degassing maps, a) Palazzo area, b) Lavinate area and c) Bollore area. The $\mathrm{CO}_{2}$ flux is reported as the probability that the simulated fluxes are higher than $50 \mathrm{~g} \mathrm{~m}^{-2} \mathrm{~d}^{-1}$. This value is assumed as the threshold for the biological $\mathrm{CO}_{2}$ flux for period of the surveys, corresponding to the average of the $95^{\text {th }}$ percentiles of the LFP-PA, LFP-LA and LFP-BO populations (see Fig. $3 \mathrm{~b}-\mathrm{d}$ and Table 2 ). Coordinates are reported in ED50/UTM32N, EPSG:23032.

et alii, 2000), Banditella (10 t d $\mathrm{d}^{-1}$; Frondini et alii, 2009) and Ermeta (12 $\mathrm{t} \mathrm{d}^{-1}$; Nisi et alii, 2014).

As a general consideration, we remark that the comparison of the detailed surveys with the GS data indicates a large overestimation of the GS-based total emission possibly arising from the large spacing between the GS measurements respect to the dimension of the DDSs.

\section{Processes CONTROLLING THE CHEMICAL AND ISOTOPIC}

COMPOSITIONS OF THERMAL SPRINGS AND GAS EMISSIONS

The sampled thermal springs (BSF springs, Table 4) are characterized by flow rates ranging from 0.01 to 24 $\mathrm{L} \mathrm{s}^{-1}$ and discharge temperatures from 23 to $48{ }^{\circ} \mathrm{C}$. Their position in the Langelier Ludwig diagram (Fig. 6) indicates that the BSF thermal waters can be interpreted as mixtures of a Ca-SO $\mathrm{SO}_{4}$ component with a $\mathrm{Ca}-\mathrm{HCO}_{3}$ hydro-type typical of the sedimentary aquifers of the region (both limestones and sandstones, CHIODINI et alii, 1988; FRONDINI et alii, 2009). Fig. 6 suggests also that there are no significant mixing processes neither with groundwaters of the volcanic aquifer nor with a liquid phase from the high enthalpy geothermal systems of AVGA.

The temperature of the springs is positively correlated with $\mathrm{SO}_{4}$ and total dissolved carbon (TDIC) while it is negatively correlated with $\mathrm{Cl}$ (Fig. 7), suggesting that the groundwaters are heated up by hot fluids rich in carbon and sulphur and poor in $\mathrm{Cl}$. Such characteristics are typical of hydrothermal-geothermal vapours: most of the carbon content of the waters would derive from the deep $\mathrm{CO}_{2}$ of the geothermal vapours and the sulphate content possibly from both dissolution of anhydrite and oxidation of deeply derived $\mathrm{H}_{2} \mathrm{~S}$. 
TABLE 4

Physical data, and chemical and isotopic compositions of the springs (concentrations expressed in $\mathrm{mmol} \mathrm{L}^{-1}, \delta^{13} \mathrm{C}_{\mathrm{TDIC}}$ in \%o vs PDB, $\delta^{18} \mathrm{O}$ and $\delta \mathrm{D}$ in \%o vs SMOW).

\begin{tabular}{|c|c|c|c|c|c|c|c|c|c|c|c|c|c|}
\hline sample & $\begin{array}{c}\mathrm{Q} \\
\left(\mathrm{L} \mathrm{s}^{-1}\right)\end{array}$ & $\begin{array}{c}\mathrm{T} \\
\left({ }^{\circ} \mathrm{C}\right)\end{array}$ & $\mathrm{pH}$ & $\mathrm{Ca}$ & $\mathrm{Mg}$ & $\mathrm{Na}$ & $\mathrm{K}$ & $\mathrm{HCO}_{3}$ & $\mathrm{SO}_{4}$ & $\mathrm{Cl}$ & $\delta^{13} C_{\text {TDIC }}$ & $\delta^{18} \mathrm{O}$ & $\delta \mathrm{D}$ \\
\hline 33 & 24.0 & 48.0 & 6.11 & 17.07 & 7.54 & 1.16 & 0.27 & 27.14 & 13.52 & 0.48 & -0.83 & -8.2 & -46.7 \\
\hline 34 & 3.0 & 39.3 & 6.28 & 12.05 & 6.14 & 1.01 & 0.23 & 18.19 & 10.94 & 0.57 & 1.51 & n.d. & n.d. \\
\hline 35 & 0.01 & 45.5 & 6.29 & 17.54 & 7.50 & 1.08 & 0.27 & 28.09 & 14.61 & 0.47 & 2.17 & -8.1 & -47.7 \\
\hline 36 & 0.1 & 35.6 & 6.12 & 9.41 & 6.43 & 0.94 & 0.22 & 13.35 & 10.65 & 0.55 & -0.08 & -7.7 & -47.0 \\
\hline 37 & 0.5 & 39.4 & 6.00 & 11.63 & 5.79 & 0.97 & 0.22 & 18.19 & 11.11 & 0.56 & -0.33 & -7.9 & -45.8 \\
\hline 38 & 4.0 & 24.3 & 6.89 & 7.59 & 6.02 & 0.95 & 0.19 & 20.54 & 8.8 & 0.79 & 1.22 & -7.8 & -45.7 \\
\hline 39 & 1.0 & 40.2 & 7.06 & 12.33 & 4.76 & 0.95 & 0.25 & 19.31 & 11.82 & 0.53 & 1.30 & -7.9 & -47.0 \\
\hline 40 & 1.0 & 40.0 & 6.25 & 11.48 & 6.51 & 1.00 & 0.26 & 17.21 & 11.83 & 0.57 & -0.41 & -7.9 & -47.8 \\
\hline 43 & 0.5 & 23.2 & 6.40 & 7.71 & 4.04 & 0.81 & 0.15 & 13.20 & 7.96 & 0.56 & 0.28 & -7.6 & -46.1 \\
\hline 44 & 1.0 & 44.5 & 6.39 & 16.77 & 7.50 & 1.08 & 0.26 & 26.78 & 14.51 & 0.48 & 1.15 & -8.2 & -46.7 \\
\hline
\end{tabular}

n.d. = not determined.

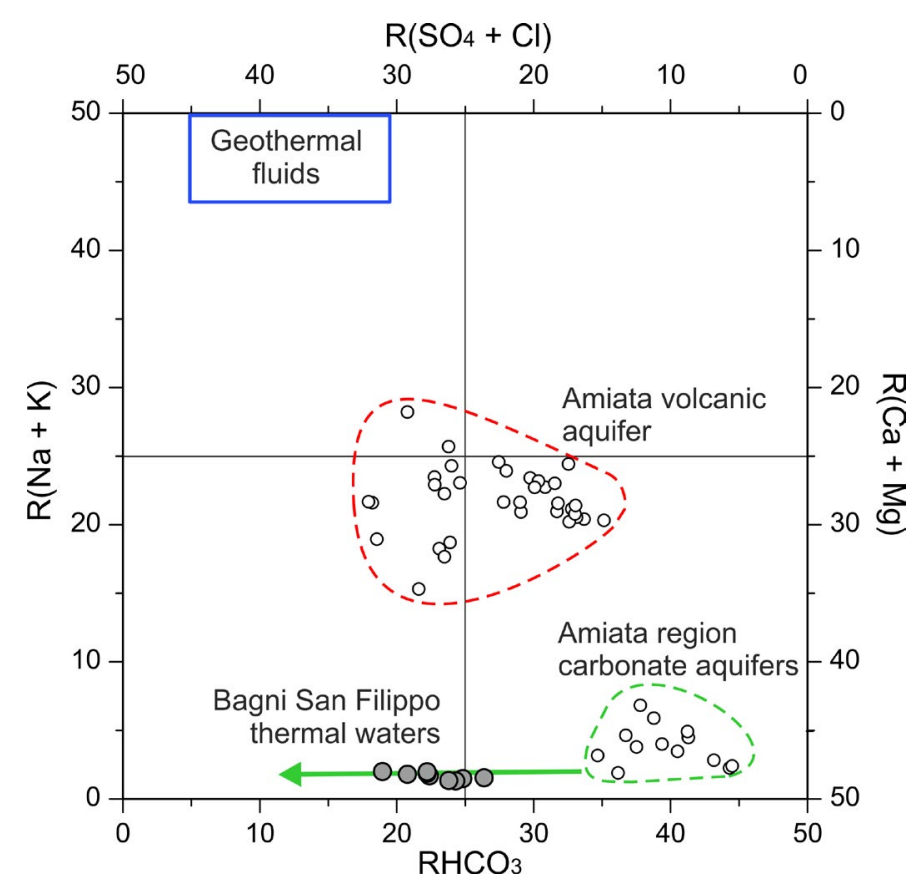

Fig. 6 - Langelier Ludwig compositional diagram. Bagni San Filippo thermal waters are compared to the waters of Mt. Amiata volcanic aquifer and groundwater from other carbonate aquifers of the region (data after Frondini et alii, 2009).

The enthalpy-chloride diagram (Fig. 8a) supports this interpretation because the BSF thermal springs fit the theoretical mixing of groundwaters with condensates of hydrothermal vapours, or directly with steam (red arrow in Fig. 8a), rather than with geothermal liquids (for comparison in the figure is considered the mean values of several Amiata geothermal wells, Minissale et alii, 1997). In the following we investigate in detail the mixing condensates-groundwaters because the alternative interpretation of the direct input of steam into the aquifer feeding the BSF thermal spring, even if possible, is less supported by the enthalpy-chloride data of the thermal springs (Fig. 8a).
The mixing between groundwaters and condensates (red line in Fig. 8a) has been drawn as the best linear fit of the BSF thermal waters and the vapour condensate at 100 ${ }^{\circ} \mathrm{C}$ (enthalpy $=419 \mathrm{~J} \mathrm{~g}^{-1}$ ) assumed with no chloride. At low enthalpy values, the regression line points to a groundwater sample (green point in Fig. 8a) that, among the many samples from sedimentary aquifers reported in FRONDINI et alii, (2009), is that closest to Bagni San Filippo area. The mixing model assumes that the enthalpy (temperature) of the BSF thermal waters, and in particular of the hottest

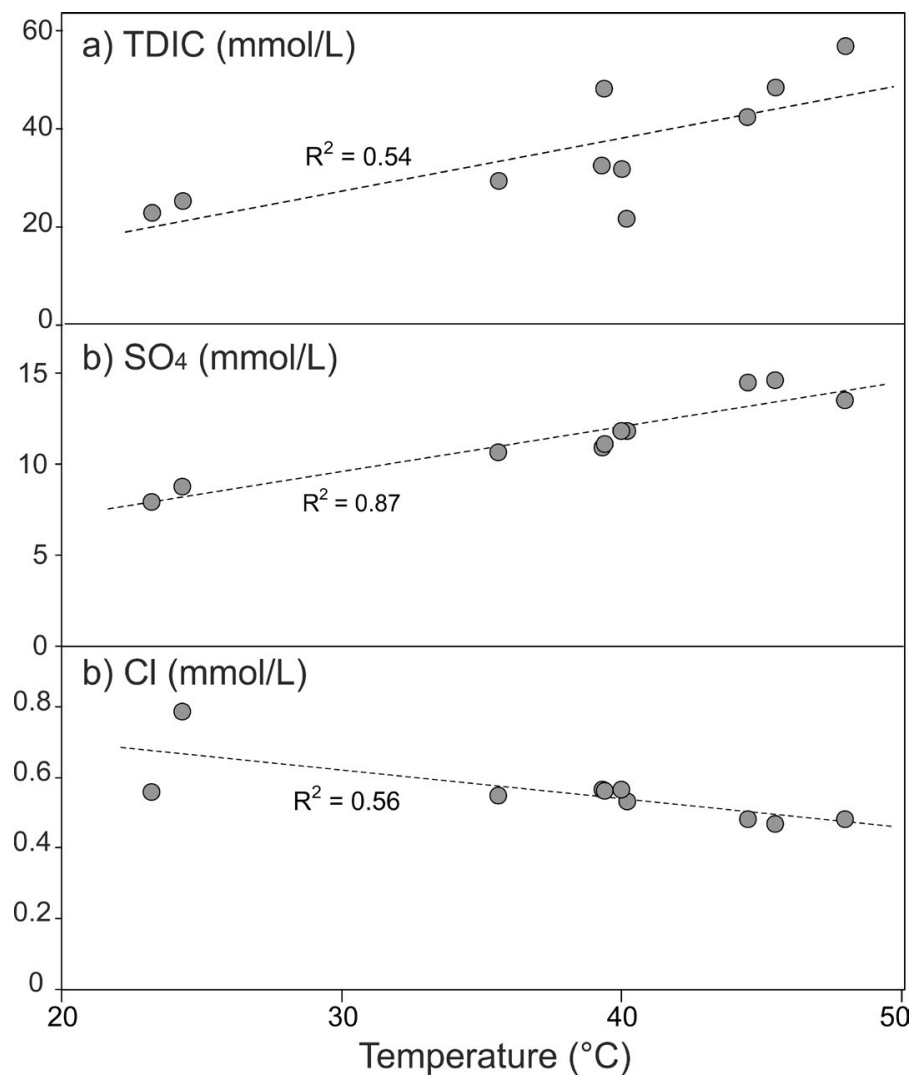

Fig. 7 - Variations of a) TDIC, b) $\mathrm{SO}_{4}$ and c) $\mathrm{Cl}$ of $\mathrm{BSF}$ thermal springs with the temperature $\left({ }^{\circ} \mathrm{C}\right)$. 

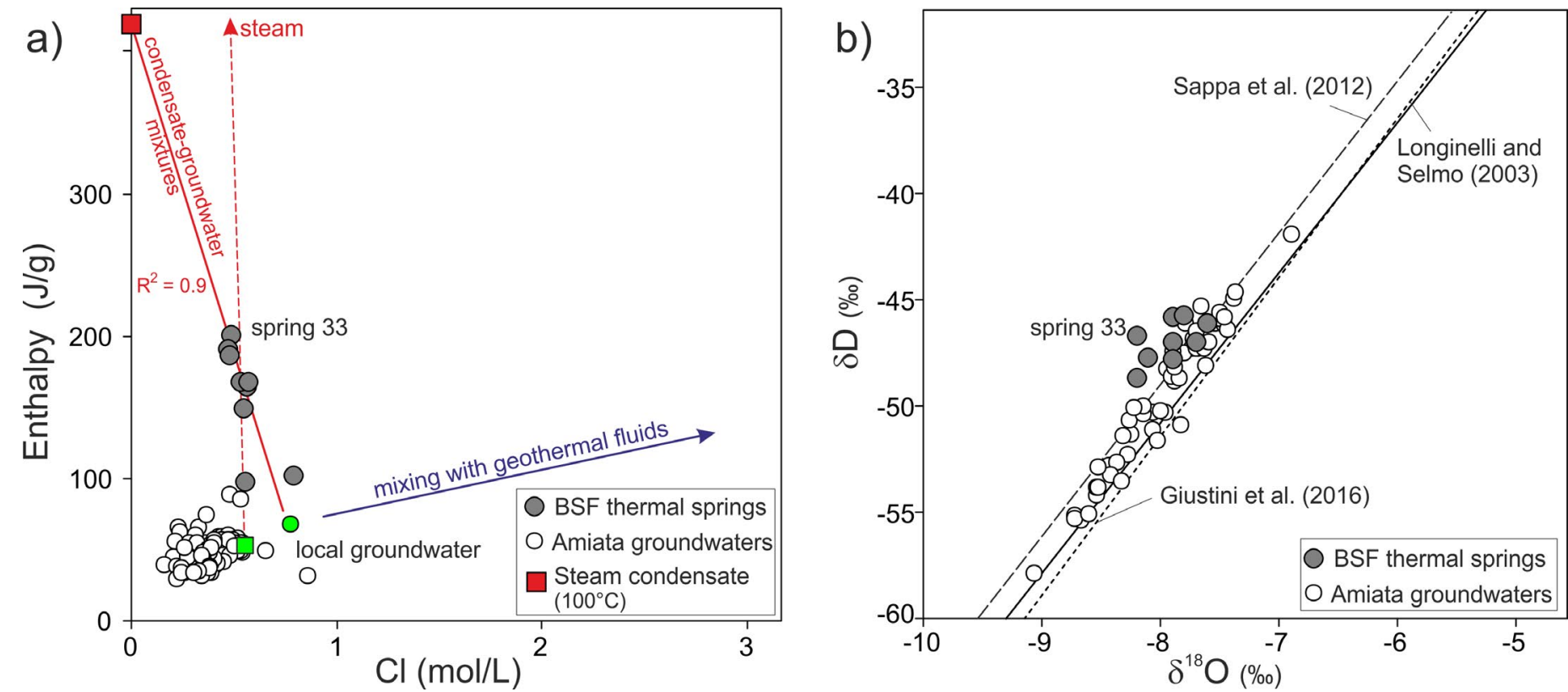

Fig. 8 - a) Enthalpy vs chloride diagram for BSF thermal springs. BSF data are compared with the normal groundwaters of the Amiata region (CHIOdini et alii, 1989; FRONDINI et alii, 2009), and with the theoretical mixtures of groundwaters with geothermal liquids of the Amiata geothermal wells (Minissale et alii, 1997), with condensates and with steam. The green symbols indicate possible groundwater end-members for mixtures with condensates (circle) and steam (square). b) $\delta \mathrm{D} v s \delta^{18} \mathrm{O}$ diagram. The BSF thermal springs plot at lighter oxygen isotopic composition with respect to both the Amiata groundwaters (data from MAGI et alii, 2019) and possible meteoric waters of the region (meteoric water lines from Longinelli \& SElmo, 2003; Sappa et alii, 2012; Giustini et alii, 2016).

spring 33 whose flow rate is $70 \%$ of the total BSF discharge (Fig. 8a), is representative of the system at depth. The estimations of the deep temperatures were attempted using the $\log (\mathrm{Ca} / \mathrm{Mg})$ geothermometer based on the equilibrium of the solutions with calcite and dolomite (MARINI et alii, 1986). The geothermometer provides estimations of 47 ${ }^{\circ} \mathrm{C}-52{ }^{\circ} \mathrm{C}$ practically coincident with the measured values of the springs of highest temperatures. This coincidence regards, in particular, the spring 33 suggesting that only a minor loss of heat occurs during the ascent of the water from depth, corroborating the reliability of the mixing model.

Interestingly in the classical $\delta \mathrm{D}$ vs $\delta^{18} \mathrm{O}$ diagram (Fig. 8b), the BSF springs plot close to the possible meteoric lines but with an evident shift towards lighter oxygen isotopic compositions. This behaviour can be explained by the input into groundwaters of meteoric origin of a vapour rich in $\mathrm{CO}_{2}$ (i.e., of condensed steam and $\mathrm{CO}_{2}$ ). In one hand the steam produced by boiling is depleted in ${ }^{18} \mathrm{O}$ and ${ }^{2} \mathrm{H}$ with respect to the parent liquid, in the other hand the $\mathrm{CO}_{2}$ can exchange the oxygen with the water causing a fractionation again toward lighter isotopic compositions.

Aqueous speciation calculations, computed by means of the PHREEQC code (PARKhURST \& APPELO, 1999), show that the $\mathrm{BSF}$ waters have partial pressures of $\mathrm{CO}_{2}\left(\mathrm{P}_{\mathrm{CO} 2}\right)$ ranging from 0.1 to 1.5 bar (Table 5) and that are all slightly undersaturated with respect to gypsum and saturated or supersaturated with respect to calcite and dolomite. This supersaturation with respect to carbonate minerals suggests that the waters at depth have higher contents of

TABLE 5

Results of aqueous speciation calculations and dissolved carbon.

\begin{tabular}{|c|c|c|c|c|c|}
\hline Sample & $\mathrm{SI}_{\text {Calcite }}$ & SI Dolomite & $\mathrm{SI}_{\text {Gypsum }}$ & $\begin{array}{l}\mathrm{PCO}_{2} \\
(\mathrm{bar})\end{array}$ & $\begin{array}{c}\text { TDIC } \\
\left(\mathrm{mol} \mathrm{kg}^{-1}\right)\end{array}$ \\
\hline 33 & 0.538 & 1.003 & -0.219 & 1.49 & 0.0570 \\
\hline 34 & 0.352 & 0.657 & -0.347 & 0.61 & 0.0327 \\
\hline 35 & 0.725 & 1.334 & -0.166 & 0.97 & 0.0485 \\
\hline 36 & -0.148 & -0.159 & -0.483 & 0.62 & 0.0295 \\
\hline 37 & 0.009 & 0.010 & -0.386 & 0.85 & 0.0461 \\
\hline 38 & 0.846 & 1.523 & -0.394 & 0.13 & 0.0251 \\
\hline 39 & 1.119 & 2.113 & -0.331 & 0.11 & 0.0218 \\
\hline 40 & 0.255 & 0.534 & -0.357 & 0.63 & 0.0319 \\
\hline 43 & 0.009 & -0.148 & -0.518 & 0.27 & 0.0229 \\
\hline 44 & 0.548 & 0.993 & -0.175 & 1.47 & 0.0561 \\
\hline
\end{tabular}


$\mathrm{CO}_{2}$. For the spring 33, assumed as representative of the system (see above), we estimated an original $\mathrm{P}_{\mathrm{CO} 2}$ of $\sim 7$ bar by adding $\mathrm{CO}_{2}$ to the solution (PHREEQC model) until reaching equilibrium conditions with calcite.

Summing up, we infer the presence at shallow depth of a system recharged by a mixture of groundwaters and condensates, a system with a temperature close to $50{ }^{\circ} \mathrm{C}$ and high $\mathrm{P}_{\mathrm{CO} 2}$. Most of the incondensable gases of the original vapour phase would be released as a free gas phase in the zones where the vapour enters the aquifer while a main part of the dissolved fraction would be released during the ascent and the depressurization of the waters. The sounding of this model is suggested also by the presence in the area of numerous gas emissions (Fig. 2, Table 6) and areas of $\mathrm{CO}_{2}$ soil diffuse degassing (Figs. 2 and 5) that would be fed from both a free gas phase present at depth and from the ascending degassing solutions.

The gas emissions have a $\mathrm{CO}_{2}$ dominated composition (Table 6) and relatively high contents of $\mathrm{CH}_{4}$ and nonatmospheric $\mathrm{N}_{2}$. The $\mathrm{CH}_{4}$ concentrations range from $1.4 \%$ to $1.9 \%$ while the $\mathrm{N}_{2}$ concentrations are of $2 \%-2.5 \%$ with $\mathrm{N}_{2} /$ Ar ratios from 2200 to 6300 (excluding the samples BSF4 and BSF10 whose $\mathrm{N}_{2} / \mathrm{Ar}$ of $\sim 100$ indicates an evident air contamination during sampling). The relative contents of $\mathrm{N}_{2}$, He and Ar of BSF gases fall in the range of other gas emissions of the TRDS (Fig. 9) that overall are enriched in $\mathrm{N}_{2}$ respect to He when compared with the gases from of the active quiescent volcanoes of the Italian Peninsula (e.g., Vesuvius, Campi Flegrei and Ischia). The relatively high $\mathrm{N}_{2} / \mathrm{He}$ (and $\mathrm{N}_{2} / \mathrm{Ar}$ ) ratios of the TRDS gases are ascribed to $\mathrm{N}_{2}$ enrichment due to the thermal decomposition of organic matter recycled through subduction (e.g., CHIODINI et alii, 2007).

Also the carbon isotopic composition of the $\mathrm{CO}_{2}\left(\delta^{13} \mathrm{C}_{\mathrm{CO} 2}\right.$ from $-2.8 \%$ to $-2.3 \%$, Table 6$)$ is in the typical range of TRDS gases $\left(\delta^{13} \mathrm{C}_{\mathrm{CO} 2}\right.$ from $-4 \%$ o to $-2 \%$, CHIODINI et alii, 2007) which have been interpreted as the result of a mixing between a $\mathrm{CO}_{2}$ produced at depth from decarbonation of carbonates and a more negative mantle $\mathrm{CO}_{2}$ (CHIODINI et alii, 2000; Chiodini et alii, 2004). We note that the carbon isotopic compositions of the BSF gas emissions are significantly lighter than the carbon dissolved in the thermal waters $\left(\delta^{13} \mathrm{C}_{\text {TDIC }}\right.$ from $-0.8 \%$ to $+2.2 \%$, Tab 4$)$. In order to investigate the processes controlling such

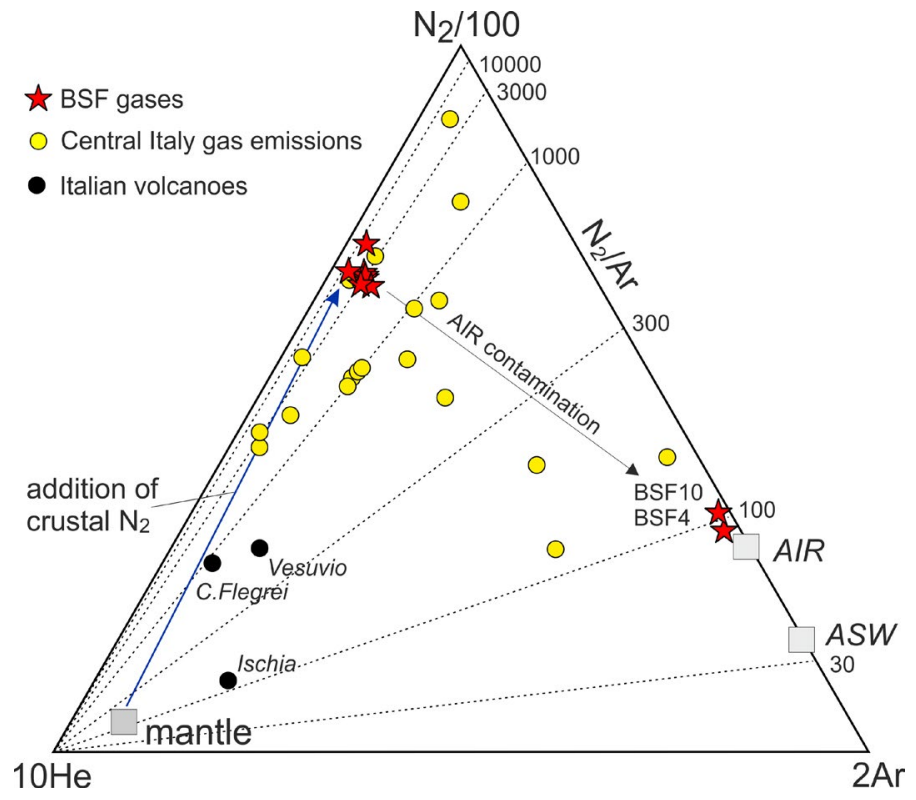

Fig. 9 - He-Ar- $\mathrm{N}_{2}$ triangular diagram. The BSF gases are compared with some other gases of TRSD and with fumarolic gases of the Neapolitan active volcanoes (data from CHIodini et alii, 2007).

differences we applied a gas-water-rock interaction model (GWRI) based on i) the PHREEQC code to manage the chemical composition of the waters, ii) the Henry law to compute the composition of the dissolved gases, and iii) data from Wigley et alii (1978) to compute the carbon isotopic fractionations during the simulated processes. The model simulates the composition of a normal groundwater affected both by the input of a deep gas and by degassing at a temperature of $50^{\circ} \mathrm{C}$, that is the temperature measured in the main springs (sample 33$)$ and returned by the log $(\mathrm{Ca} /$ $\mathrm{Mg}$ ) geothermometer.

According to the results of many investigation in the carbonate aquifers of the Apennines (e.g., FRONDINI et alii, 2019 and references therein) the total dissolved inorganic carbon (TDIC) of the normal groundwater is set at 0.0035 mol $\mathrm{L}^{-1}$ with a carbon isotopic composition of $-10 \%$, a value controlled by the mixing among the atmospheric carbon, the biogenic carbon of the soil $\mathrm{CO}_{2}$, and the carbon

TABLE 6

Chemical and isotopic composition of the gas emissions (concentrations expressed in $\mu \mathrm{mol} \mathrm{mol}^{-1}$ ).

\begin{tabular}{|c|c|c|c|c|c|c|c|c|c|c|c|}
\hline Sample & date & $\mathrm{CO}_{2}$ & $\mathrm{H}_{2} \mathrm{~S}$ & $\mathrm{Ar}$ & $\mathrm{O}_{2}$ & $\mathrm{~N}_{2}$ & $\mathrm{CH}_{4}$ & $\mathrm{H}_{2}$ & $\mathrm{He}$ & $\mathrm{CO}$ & $\begin{array}{c}\delta^{13} \mathrm{C}_{\mathrm{CO} 2} \\
(\% \text { vs } \mathrm{PDB})\end{array}$ \\
\hline BSF1 & $21 / 11 / 2003$ & 960700 & 1750 & 7.26 & 17.72 & 23580 & 13980 & 0.89 & 9.70 & 0.15 & -2.61 \\
\hline BSF4 & $21 / 11 / 2003$ & 844700 & n.d. & 1250 & 28350 & 130000 & 14520 & 0.41 & 5.47 & 0.27 & -2.81 \\
\hline BSF5 & $22 / 11 / 2003$ & 957200 & 1554 & 7.99 & 0 & 22400 & 18860 & 0.84 & 9.39 & 1.01 & n.d. \\
\hline BSF5 & $23 / 11 / 2003$ & 957900 & 1778 & 7.54 & 22 & 22290 & 17990 & 0 & 9.25 & 0.06 & n.d. \\
\hline BSF-F1 & $18 / 12 / 2003$ & 958500 & 1707 & 9.37 & 0.29 & 20590 & 19210 & 2.85 & 8.73 & 0.17 & n.d. \\
\hline BSF-F2 & $18 / 12 / 2003$ & 959200 & 1684 & 7.01 & 0.38 & 20190 & 18930 & 3.24 & 8.87 & 0.22 & -2.3 \\
\hline BSF8 & $19 / 02 / 2004$ & 959100 & 1770 & 3.45 & 0.3 & 20580 & 18520 & 0 & 7.30 & 0.29 & n.d. \\
\hline BSF9 & $19 / 02 / 2004$ & 959000 & 1752 & 3.99 & 1.0 & 24980 & 14260 & 0.83 & 10.89 & 0.34 & -2.3 \\
\hline BSF10 & $20 / 02 / 2004$ & 932100 & 1039 & 569 & 11330 & 52870 & 2046 & 1.67 & 3.06 & 1.02 & n.d. \\
\hline
\end{tabular}

n.d. = not determined. 
from calcite dissolution $\left(\delta^{13} \mathrm{C}=+2.5 \%\right.$ ). The chemical and isotopic composition of the deep gas has been assumed as that of BSF9, the gas emission less affected by air contamination (i.e., $\mathrm{N}_{2} / \mathrm{Ar}=6260,2$ orders of magnitude higher than air and the highest among the sampled gas emissions). In the model the deep gas is added until the solution reaches a $\mathrm{P}_{\mathrm{CO} 2}$ of 7 bars (see above) and allowing the solution to dissolve calcite at equilibrium conditions (curve A in Fig. 10). The solution is then depressurised (without allowing calcite precipitation as suggested by the supersaturation of the springs) down to the lowest measured $\mathrm{P}_{\mathrm{CO} 2}$ values (i.e. 0.2 bar, curve $\mathrm{B}$ in Fig. 10). In general the measured $\delta^{13} \mathrm{C}_{\mathrm{TDIC}}$ and TDIC of BSF thermal springs follow this trend of depressurizing solutions that have reached relatively high $\mathrm{P}_{\mathrm{CO} 2}$ at depth. In particular, the model results fit the data of the main and hottest spring 33 (Fig. 10).

\section{CONCEPTUAL MODEL OF THE SYSTEM AND FLOW RATES OF DEEP $\mathrm{CO}_{2}$} AND STEAM CONDENSATE

Our conceptual model of the BSF system is sketched in Fig. 11. The thermal springs of BSF are recharged in the Mt. Poggio Zoccolino area where permeable carbonate rocks outcrop. The recharge area is separated from the discharge area, that is less than 2 kilometres distant (Fig. 1), by a zone (gas emissions zone in Fig. 11) where the hydrothermal condensates likely enter into the shallow aquifer.

Note that in this model the vapour condensation should occur at depths greater than that of groundwater circulation because our evidence is the input of a hot liquid plus a separated gas phase rather than of a high enthalpy vapour phase (Fig. 8a). This zone, separating the recharge and discharge areas, is the zone where most of the incondensable gases are emitted as testified by the presence of numerous free $\mathrm{CO}_{2}$ emissions. This is also the zone that was surveyed for diffuse soil $\mathrm{CO}_{2}$ fluxes (Figs.1 and 2), whose results indicate a total deep $\mathrm{CO}_{2}$ flux of 160$210 \mathrm{t} \mathrm{d}^{-1}$ (see section 4.1). Considering the $\mathrm{CO}_{2}$ emission from the gas vents (estimated in 50-100 $\mathrm{t} \mathrm{d}^{-1}$, TASsI et alii, 2009) and the amount of $\mathrm{CO}_{2}$ dissolved and transported by the waters $\left(6.4 \mathrm{t} \mathrm{d}^{-1}\right.$ computed as the sum of the TDIC of the springs multiplied by their flow rates) our best estimation of the total deep $\mathrm{CO}_{2}$ emission at BSF is at 226-326 $\mathrm{t} \mathrm{d}^{-1}$.

The condensate flow rate is evaluated from the fraction of condensates that feed the BSF thermal springs. The enthalpy and chloride mass balance applied to the mean springs value (weighted by the respective flow rate), assuming as pure end-members the condensate and the normal groundwater (Fig. 8a), indicates that $\sim 11.2 \mathrm{~kg} \mathrm{~s}^{-1}$ (965 $\left.\mathrm{t} \mathrm{d}^{-1}\right)$, of the total $35 \mathrm{~kg} \mathrm{~s}^{-1}$ thermal water discharge, are of condensates. Summing up, the deep $\mathrm{CO}_{2}$ emission is of $226-326 \mathrm{t} \mathrm{d}^{-1}$ and the condensate flow rate is of $965 \mathrm{t} \mathrm{d}^{-1}$, values that point to the input of a vapour phase with a $\mathrm{CO}_{2}$ molar fraction $\mathrm{X}_{\mathrm{CO} 2}$ of $0.08-0.12\left(\mathrm{X}_{\mathrm{CO} 2}=\mathrm{mol}_{\mathrm{CO} 2} /\left(\mathrm{mol}_{\mathrm{con}}\right.\right.$ $\left.+\mathrm{mol}_{\mathrm{CO} 2}\right)$ ). This is plausible $\mathrm{X}_{\mathrm{CO} 2}$ range for a geothermal vapour (e.g., $\mathrm{X}_{\mathrm{CO} 2}$ measured in several geothermal wells of Amiata region range from 0.07 to 0.12 ; CHIODINI \& MARINI, 1998). The total thermal energy release involved in the condensation (latent heat of condensation) and in the cooling of the condensates would result at $\sim 29 \mathrm{MW}$. Of this total thermal energy release, $\sim 4 \mathrm{MW}$ are associated with the BSF thermal discharge while the remaining $25 \mathrm{MW}$

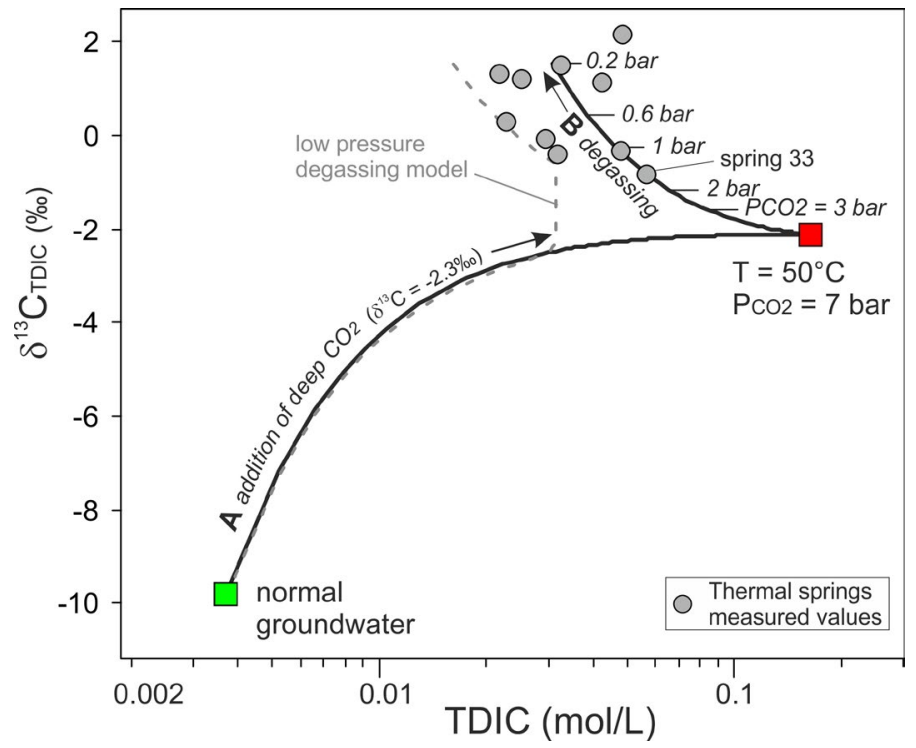

Fig. 10 - Diagram $\delta^{13} \mathrm{C}_{\text {TPIC }}$ vs TDIC showing the results of the GWRI model (see the text). The dashed grey line refers to a low pressure degassing model that simulate the contemporary input of the deep $\mathrm{CO}_{2}$ and the degassing of the dissolved gases at a pressure of 1 bar. This low pressure degassing model could explain the composition of the spring with lower TDIC contents.

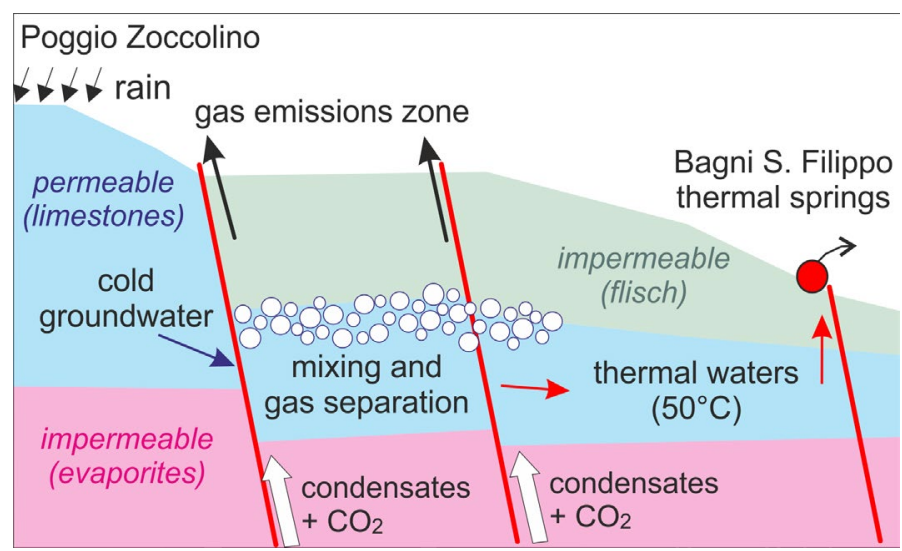

Fig. 11 - Conceptual model of BSF thermal springs and gas emissions.

would refer to deeper processes, i.e. the steam condensation occurring at depths greater than groundwater circulation.

These results are dependent on the selected mixing model, if, e.g., we assume the alternative model of the input of steam (condensation directly into the aquifer, dashed red arrow in Fig. 8a) the estimated flux of condensates formed into the aquifer, $\mathrm{X}_{\mathrm{CO} 2}$ of the pre-condensed vapour and the thermal energy release would be of $146 \mathrm{t} \mathrm{d}^{-1}, 0.38-0.48$, and 4.5 MW, respectively.

\section{CONCLUSIONS}

Thermal waters of $\mathrm{Ca} \mathrm{HCO}_{3}-\mathrm{SO}_{4}$ composition and temperatures up to $48^{\circ} \mathrm{C}$, and numerous cold emissions of large amounts of $\mathrm{CO}_{2}$, both from soil diffuse degassing and vents, occur in Bagni San Filippo area, an area of few $\mathrm{km}^{2}$. We individuate in ascending geothermal 
vapours the source of both the gas emission and the high temperatures of the waters. The thermal waters are in fact mixtures of condensates of hydrothermal steam (or, less likely, of steam) with locally recharged waters, whereas the cold gas emissions are fed by the incondensable gases originally contained in the ascending vapours. This conceptual model is supported by the temperature of the springs that is negatively correlated with the chloride and positively with sulphate and dissolved carbon suggesting that groundwaters are heated up by hot fluids rich in carbon and sulphur and poor in $\mathrm{Cl}$, such as typical hydrothermal vapours. In agreement with this model, the isotopic compositions of the carbon dissolved in the thermal waters and that of the cold $\mathrm{CO}_{2}$ emissions point to a unique deep carbon source $\left(\delta^{13} \mathrm{C}=-2.3 \%\right.$ ). In a first stage, the condensates and the deep-originated $\mathrm{CO}_{2}$ enter the shallow aquifer causing a temperature increase to $50^{\circ} \mathrm{C}$ and elevated $\mathrm{P}_{\mathrm{CO} 2}(\sim 7$ bar $)$. In a second phase, the ascending thermal solutions depressurize and release a great part of the gas contributing to the observed $\mathrm{CO}_{2}$ emission. We computed at $11.2 \mathrm{~kg} \mathrm{~s}^{-1}$ the amount of condensate transported by the springs, whose total flow rate is of $35 \mathrm{~kg} \mathrm{~s}^{-1}$, and at $\sim 29 \mathrm{MW}$ the total thermal energy release. Most of this heat flux $(\sim 25 \mathrm{MW})$ is associated with the condensation occurring at depths greater than groundwater circulation. Assuming alternatively that the condensation process occurs directly into the aquifer (i.e., input of steam instead of condensate, less probable but possible) the flux of condensates would reduce at 1.7 $\mathrm{kg} \mathrm{s}^{-1}$, with a thermal energy release at 4.5 MW.

The location of the deep $\mathrm{CO}_{2}$ gas emission, both vents and diffuse degassing structures, is strongly controlled by the tectonic lineaments. Diffuse $\mathrm{CO}_{2}$ flux surveys were performed to quantify the deep $\mathrm{CO}_{2}$ emission from this area. The analysis of the data of a first general measurement campaign indicates a spatial variably of the fluxes larger than the spacing between the measurements, a fact that implies a large overestimation of the deep $\mathrm{CO}_{2}$ emission $\left(\sim 850 \mathrm{t} \mathrm{d}^{-1}\right)$. For this reason we performed specific, more detailed, campaigns focussed on three of the most anomalous zones obtaining a total deep $\mathrm{CO}_{2}$ flux of $130 \mathrm{t} \mathrm{d}^{-1}$ from diffuse degassing. Our best estimation of the total deep $\mathrm{CO}_{2}$ emission becomes of 226-326 t d $\mathrm{d}^{-1}$ when the fluxes estimated for other two anomalous degassing areas, from gas vents and that transported as dissolved carbon by the thermal waters are considered. Combining the estimated fluxes of deep $\mathrm{CO}_{2}$ and condensate we infer that the original pre-condensed vapour has a $\mathrm{CO}_{2}$ molar fraction of $0.08-0.12$, a possible range for a geothermal vapour that, e.g., is similar to the $\mathrm{CO}_{2}$ molar fractions measured in the nearby Amiata geothermal wells.

Finally, this work highlights, as already evidenced in previous works (e.g., CARDELlini et alii, 2003; Viveiros et alii, 2010; BINI et alii, 2019), that to obtain a reliable picture of the $\mathrm{CO}_{2}$ spatial distribution and a reliable estimation of the $\mathrm{CO}_{2}$ output an appropriate sampling density must be adopted in relation to the spatial structure of the $\mathrm{CO}_{2}$ flux. In particular, it is necessary to use a measurement spacing suitable for the extent of the degassing anomalies, which can be estimated through the variographic analysis of the data (i.e., through the range of the variogram, CARDELLINI et alii, 2003).

\section{ELECTRONIC SUPPLEMENTARY MATERIAL.}

The Supplementary Material includes the datasets of the measured $\mathrm{CO}_{2}$ flux from the soil.

\section{AcKNOWLEDGMENTS.}

We wish to thank F. Tassi and an anonymous reviewer for the helpful comments and suggestions which improved the quality of the manuscript. This study was financially supported by the MIUR project n. PRIN2017-2017LMNLAW “Connect4Carbon”.

\section{REFERENCES}

Baldi P., Bellani S., Ceccarelli A., Fiordelisi A., Souarci P. \& Taffi L. (1994) - Correlazione tra le anomalie termiche ed altri elementi geofisici e strutturalidella Toscana Meridionale. Studi Geol. Camerti, 1 (Spec. Issue), 139-149.

Batini F., Brogi A., Lazzarotto A., Liotta D. \& Pandeli E. (2003) Geological features of Larderello-Travale and Mt. Amiata geothermal areas (southern Tuscany, Italy). Episodes, 26, 239-244.

Bertini G., Cappetti G., Dini I. \& Lovari F. (1995) - Deep drilling results and updating ofgeothermal knowledge of the Monte Amiata area. In: Proc. World Geothermal Congress, Florence, Italy, 18-31 May 1995, International Geothermal Association 2, pp. 1283-1286.

Bini G., Chiodini G., Cardellini C., Vougioukalakis G.E. \& Bachmann O. (2019) - Diffuse emission of $\mathrm{CO}_{2}$ and convective heat release at Nisyros caldera (Greece). J. Volcanol. Geother. Res., 376, 44-53.

Boni C., Bono P. \& CAPelli G. (1986) - Schema idrogeologico dell'Italia centrale. Mem. Soc. Geol. Ita., 35, 991-1012.

Brogi A., Lazzarotto A., Liotta D., Ranalli G. \& CROP 18 Working GRoup (2005) - Crustal structures in the geothermal areas of southern Tuscany (Italy): Insights from CROP 18 deep seismic reflection lines. J. Volcanol. Geother. Res., 148, 60-80.

Brogi A. \& Liotta D. (2006) - Understanding the crustal structures of southern Tuscany: The contribution of the CROP18 Project. Boll. Geofis. Teor. Appl., 47, 401-423.

BRogi A \& FABBRINI L. (2009) - Extensional and strike-slip tectonics across the Monte Amiata-Monte Cetona transect (Northern Apennines, Italy) and seismotectonic implications. Tectonophis., 476, 195-209.

Brogi A., Liotta D., Meccheri M. \& Fabbrini L. (2010) - Transtensional shear zones controlling volcanic eruptions: the Middle Pleistocene Mt Amiata volcano (inner Northern Apennines, Italy. Terranova, 22, 137-146.

Brogi A., Capezzuoli E., Liotta D. \& Meccheri M. (2015) - The Tuscan Nappe structures in the Monte Amiata geothermal area (central Italy): a review. Ital. J. Geosci., 134, 219-236.

Calamai A., Cataldi R., Souarci P. \& TAFFi L. (1970) - Geology, geophysics and hydrogeology of Monte Amiata geothermal fields. Geothermics, 1 (Spec. Issue), 1-9.

Cardellini C., Chiodini G. \& Frondini F. (2003) - Application of stochastic simulation to $\mathrm{CO}_{2}$ flux from soil: mapping and quantification of gas release. J. Geophys. Res., 108, 2425.

Cardellini C., Chiodini G., Frondini F., Avino R., Bagnato E., Caliro S Lelli M. \& Rosiello A. (2017) - Monitoring diffuse volcanic degassing during volcanic unrests: the case of Campi Flegrei (Italy). Sci. Rep., 7, 6757 .

Carmignani L., Decandia F.A., Disperati L., Fantozzi P.L., Lazzarotto A., Liotta D. \& Oggiano G. (1995) - Relationships between the Tertiary structural evolution of the Sardinia-Corsica-Provençal Domain and the Northern Apennines. Terra Nova, 7, 128-137.

Celati R., Grassi S. \& Calore C. (1990) - Overflow thermal springs of Tuscany (Italy). J. Hydrol., 118, 191-207.

Chiodini G., Comodi P., Giaquinto S., Mattioli B. \& Zanzari A.R. (1988) Cold Groundwater temperatures and conductive heat flow in the Mt. Amiata geothermal area, Tuscany, Italy. Geothermics, 17, 645-656.

Chiodini G., \& MARINI L. (1998) - Hydrothermal gas equilibria: the $\mathrm{H}_{2} \mathrm{O}$ $\mathrm{H}_{2}-\mathrm{CO}_{2}-\mathrm{CO}-\mathrm{CH}_{4}$ system. Geochim. Cosmochim. Acta, 62, 2673-2687.

Chiodini G., Cioni R., Guidi M., Raco B. \& Marini L. (1998) - Soil CO flux measurements in volcanic and geothermal areas. Appl. Geochem., 13, 543-552.

Chiodini G., Frondini F., Kerrick D.M., Rogie J., Parello F., Peruzzi L. \& ZANZARI A.R. (1999) - Quantification of deep CO fluxes from Central Italy. Examples of carbon balance for regional aquifers and of soil diffuse degassing. Chem. Geol., 159, 205-222. 
Chiodini G., Frondini F., Cardellini C., Parello F. \& Peruzzi L. (2000) Rate of carbon dioxide Earth degassing estimated from the carbon balance of regional aquifers: The case of central Apennine (Italy). J. Geophys. Res., 105, 8423-8434.

Chiodini G., Frondini F., Cardellini C., Granieri D., Marini L. \& Ventura G. (2001) - $\mathrm{CO}_{2}$ degassing and energy release at Solfatara volcano, Campi Flegrei, Italy. J. Geophys. Res., 16213-16221.

Chiodini G., Cardellini C., Amato A., Boschi E., Caliro S., Frondini F. \& VentuRA G. (2004) - Carbon dioxide Earth degassing and seismogenesis in central and southern Italy. Geophys. Res. Lett., 31, L07615.

Chiodini G., Baldini A., Barberi F., Carapezza M. L., Cardellini C., Frondini F., GRANIERI D. \& RANAldi M. (2007) - Carbon dioxide degassing at Latera caldera (Italy): Evidence of geothermal reservoir and evaluation of its potential energy. J. Geophys. Res., 112, B12204.

Chiodini G., Valenza M., Cardellini C. \& Frigeri A. (2008) - A new webbased catalog of Earth degassing sites in Italy. Eos, 89, 341-348.

Chiodini G., Granieri D., Avino R., Caliro S., Costa A., Minopoli C. \& VILARDO G. (2010) - Non-volcanic CO Earth degassing: Case of Mefite d'Ansanto (southern Apennines), Italy. Geophys. Res. Lett., 37 L11303.

Chiodini G., Caliro A., Cardellini C., Frondini F., Inguaggiato S. \& Matteucci F. (2011) - Geochemical evidence for and characterization of $\mathrm{CO}_{2}$ rich gas sources in the epicentral area of the Abruzzo 2009 earthquakes. Earth Planet. Sci. Lett., 304, 389-398.

Collettini C., Cardellini C., Chiodini G., De Paola N., Holddsworth R. E. \& SмIтH S.A.F. (2008), Fault weakening due to $\mathrm{CO}_{2}$ degassing in the Northern Apennines: short- and long-term processes, in The Internal Structure of Fault Zones: Implications for Mechanical and Fluid-Flow Properties, edited by C. A. J. Wiberley, W. Kurz, J. Imber, R. E. Holddsworth and C. Collettini, pp. 175-194, Geological Society, London.

Conticelli S., Boari E., Burlamacchi L., Cifelli F., Moscardi F., Laurenzi M.A., Ferrari Pedraglio L., Francalanci L., Benvenuti M.G., Brasch E. \& ManetTI P. (2015) - Geochemistry and Sr-Nd-Pb isotopes of Monte Amiata Volcano, Central Italy: evidence for magma mixing between high-K calc-alkaline and leucititic mantle-derived magmas. Ital. J. Geosci., 134, 268-292.

Costa A., Chiodini G., Granieri D., Folch A., Hankin R. K. S., Caliro S. Avino R. \& CARDELLINI C. (2008) - A shallow-layer model for heavy gas dispersion from natural sources: Application and hazard assessment at Caldara di Manziana, Italy. Geochem. Geophys. Geosys., 9, Q03002.

Davidson E., Belk E. \& Boone R. (1998) - Soil water content and temperature as independent or confounded factors controlling soil respiration in a temperate mixed hardwood forest. Glob. Chang. Biol., 4, 217-227.

Deutsch C. V. \& Journel A.G. (1998) - GSLIB: Geostatistical Software Libraryand Users Guide. Oxford Univ. Press, New York, 369 pp.

Elter F.M. \& PANDELI E. (1991) - Structural features of the metamorphic Paleozoic-Triassic sequences in deep geothermal drillings of the Monte Amiata area (SE Tuscany, Italy). Boll. Soc. Geol. Italy, 110, 511-522.

Ferrari L., Conticelli S., Burlamacchi L. \& Manetti P. (1996) Volcanological evolutionof the Monte Amiata, Southern Tuscany: new geological and petrochemicaldata. Acta Vulcanol., 8, 41-56.

Frezzotti M.L., Peccerillo A. \& Panza G. (2009) - Carbonate metasomatism and $\mathrm{CO}_{2}$ lithosphere-asthenosphere degassing beneath the Western Mediterranean: an integrated model arising from petrological and geophysical data. Chem. Geol., 262, 108-120.

Frondini F., Caliro S., Cardellini C., Chiodini G., Morgantini N. \& Parello F. (2008) - Carbon dioxide degassing from Tuscany and Northern Latium (Italy). Global Planet. Chang., 61, 89-102.

Frondini F., Caliro S., Cardellini C., Chiodini G. \& Morgantini N. (2009) - Carbon dioxide degassing and thermal energy release in the Monte Amiata volcanic-geothermal area (Italy). Appl. Geochem., 24, 860875.

Frondini F., Cardellini C., Caliro S., Beddini G., Rosiello A. \& Chiodini G. (2019) - Measuring and interpreting $\mathrm{CO}_{2}$ fluxes at regional scale: the case of the Apennines, Italy. J. Geol. Soc., 176, 408-416.

GIGGENBACH W. F. (1975) - A simple method for the collection and analysis of volcanic gas samples. Bull. Volcanol., 39(1), 132-145.

Giggenbach W. F. \& Gouguel R. L. (1989) - Collection and analysis of geothermal volcanic water and gas discharges. Chemistry Division, DSIR, New Zealand. Report no. CD 2401
Giustini F., BRilli M. \& Patera A. (2016) - Mapping oxygen stable isotopes of precipitation in Italy. J. Hydrol. Reg. Stud., 8, 162-181.

Longinelu A. \& Selmo E. (2003) - Isotopic composition of precipitation in Italy: a first overall map. J. Hydrol., 270, 75-88.

Magi F., Doveri M., Menichini M., Minissale A. \& Vaselli O. (2019) Groundwater response to local climate variability: hydrogeological and isotopic evidences from the Mt. Amiata volcanic aquifer (Tuscany, central Italy). Rend. Fis. Acc. Lincei, 30, 125-136.

Manzella A., Serra D., Cesari G., Bargiacchi E., Cei M., Cerutti P., Conti P., Giudetti G., Lupi M. \& VACCARo M. (2019) - Geothermal Energy Use, Country Update for Italy. In: Proc. European Geothermal Congress, Den Haag, The Netherlands, 11-14 June 2019, pp. 1-19.

Marini L., Chiodini G. \& Cioni R. (1986) - New geothermometers for carbonate-evaporite geothermal reservoirs. Geothermics, 15, 77-86.

Marroni M., Moratti G., Costantini A., Conticelli S., Benvenuti M.G., Pandolfi L., Bonini M., Cornamusini G. \& Laurenzi M.A. (2015a)Geology of the Monte Amiata region, Southern Tuscany, Central Italy. Ital. J. Geosci., 134, 171-199.

Marroni M., Pandeli E., Pandolfi L. \& Catanzariti R. (2015b) - Updated picture of the Ligurian and sub-Ligurian units in theMt. Amiata area (Tuscany, Italy): elements for their correlation in the framework of the Northern Apennines. Ital. J. Geosci., 134, 200-218.

Minissale A., Magro G., Vaselli O., Verrucchi C. \& Perticone I. (1997) Geochemistry of water and discharges from Mt. Amiata silicic complex and surrounding areas (central Italy). J. Volcanol. Geotherm. Res., 79, 223-251.

Minissale A., Vaselli O., Tassi F., Magro G. \& Grechi G.P. (2002) - Fluid mixing in carbonate acquifers near Rapolano (central Italy): chemical and isotopic constraints. Appl. Geochem., 17, 1329-1342.

Nisi B., Vaselli O., Tassi F., de Elio J., Ortega M., Caballero J., Rappuoli D. \& MAZADIEGO L.F. (2014) - Origin of the gases released from the Acqua Passante and Ermeta wells (Mt. Amiata, central Italy) and possible environmental implications for their closure. Annal. Geophys., 57, S0438.

Pandeli E., Bertini G., Castellucci P., Morelli M. \& Monechi S. (2005) - The sub-Ligurian and Ligurian units of the Mt.Amiata geothermal region (south-eastern Tuscany): new stratigraphic and tectonic data and insights into their relationships with the Tuscan Nappe. Boll. Soc. Geol. It., vol. spec., 3, 55-71.

Parkhurst D.L. \& Appelo C.A.J. (1999) - A Computer Program for Speciation, Batch-Reaction, One-Dimensional Transport, and Inverse Geochemical Calculations. U.S. Geological Survey, Water Resources Investigations Report 99-4259, Washington DC.

RAICH J. W., \& SCHLESINGER W. H. (1992) - The global carbon dioxide flux in soil respiration and its relationship to vegetation and climate. Tellus, 44, 81-99.

Rogie J. D., Kerrick D. M., Chiodini G. \& Frondini F. (2000) - Measurements of non volcanic $\mathrm{CO}$ emission from some vents in central Italy. J. Geophys. Res.,105, 8435-8445.

SAPpa G., Barbieri M., Ergul S. \& Ferranti F. (2012) - Hydrogeological conceptual model of groundwater from carbonate aquifers using environmental isotopes $\left({ }^{18} \mathrm{O},{ }^{2} \mathrm{H}\right)$ and chemical tracers: a case study in Southern Latium Region, Central Italy. J Water Resource Prot., 4 695-716.

SincLaIR, A. J. (1974)- Selection of threshold values in geochemical data using probability graphs. J. Geochem. Explor., 3, 129-149.

Tassi F., Vaselli O., Cuccoli F., Buccianti A., Nisi B., Lognoli E. \& Montegrossi G. (2009) - A Geochemical Multi-Methodological Approach in Hazard Assessment of $\mathrm{CO}_{2}$-Rich Gas Emissions at Mt. Amiata Volcano (Tuscany, Central Italy). Water Air Soil Poll.: Focus, 9, 117-127.

Viveiros F., Cardellini C., Ferreira T., Caliro S., Chiodini G. \& Silva C. (2010) - Soil CO emissions at Furnas volcano, Sao Miguel Island Azores archipelago: Volcano monitoring perspectives, geomorphologic studies, and land use planning application. J. Geophys. Res., 115, B12208.

Wigley T.M.L., Plummer L.N. \& Pearson F.J. JR (1978) - Mass transfer and carbon isotope evolution in natural water systems. Geochim. Cosmochim. Acta, 8, 1117-1139. 